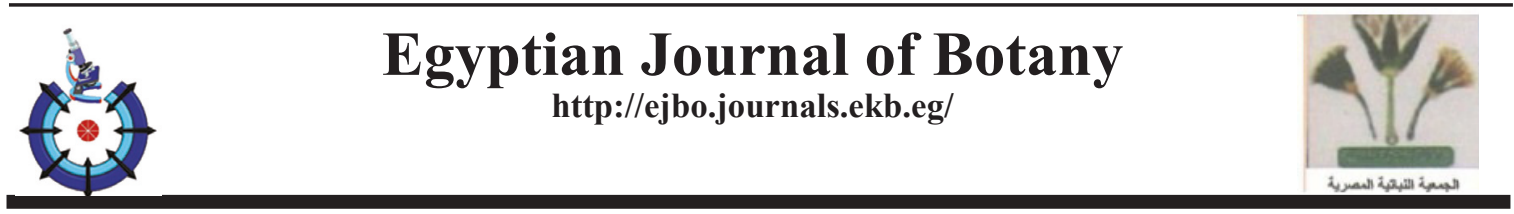

\title{
First Palynological Record from the Upper Carboniferous/ Lower Permian Succession in West Beni Suef Basin, Egypt, with Paleoecological and Paleogeographical Implications
}

\author{
Zainab M. El Noamani ${ }^{(1) \#}$, Sameh S. Tahoun ${ }^{(2)}$ \\ (1) Botany Department, Faculty of Science, Ain Shams University, Cairo, 11566, Egypt; \\ (2)Department of Geology, Faculty of Science, Cairo University, Giza, 12613, Egypt.
}

\begin{abstract}
$\mathbf{F}$ OR THE FIRST time, a palynological assemblage was recovered from the Safi Formation in the west Beni Suef Basin of the Western Desert in Egypt. A total of 65 miospore taxa were recognized; they included 31 species of pteridophyte spores (related to 20 genera) and 34 species of gymnosperm pollen (related to 14 genera). The dominance of monosaccate pollen confirms an age not older than Westphalian (Late Carboniferous) as documented in various Gondwanan basins. Besides the restricted presence and limited counts of typical guide taeniate bisaccate and non-taeniate bisaccate pollen in the present assemblage constrain and limit the age to the Asselian (Early Permian) and not younger. The paleovegetation of the studied palynoassemblage is reconstructed based on the paleobotanical affinities of the identified miospores, which are generally consistent with other macrofloral fossil records obtained from Egyptian outcrops during the Late Carboniferous and Early Permian. The paleoecological significance of the reconstructed paleovegetation enabled the recognition of two paleofloral communities: A lowland paleoflora represented by a cold climate wetland fern community associated with Lycopsida and Sphenopsida and an upland paleoflora dominated by a primitive group of gymnospermic plants with a unique moistureindependent reproduction strategy developed under the influence of a glacial climate. The high representation of the bilaterally or radially symmetrical monosaccate pollen genera, which are typical Late Paleozoic Gondwanan gymnospermic vegetation, in the present material supports the hypothesis that Egypt's Western Desert was part of the Gondwanan floral province during the Late Carboniferous/Early Permian.
\end{abstract}

Keywords: Egypt, Gondwana Province, Late Carboniferous/Early Permian, Miospores, Paleoecology, Paleogeography.

\section{Introduction}

Previously identified Paleozoic outcrops in Egypt occupy a small area of the country and are represented by a thick sequence in northwest Egypt, a thinner sequence in the Gulf of Suez/ Sinai area and scattered patches in the country's extreme southern region (at the Gebel Oweinat and Abu Ras-Wadi Malik areas, Western Desert and the northern Wadi Qena, Eastern Desert) (Klitzsch, 1990; Tawadros, 2011). For the subsurface Paleozoic rocks, drilling exploration companies have disclosed the widespread occurrence of such strata in Northern Egypt and in the Gulf of Suez area (Tawadros, 2011). Although such surface and subsurface Paleozoic deposits have been observed, thorough palynological investigations of these deposits in Egypt have not been conducted despite the focus on equivalent deposits in the same phytogeoprovince in Brazil, Libya and Saudi Arabia. This limitation may be attributed to the fact that Paleozoic deposits are relatively deep and commonly obtained 4-5 kilometers beneath the surface (EGPC, 1992; Schlumberger, 1995; Tawadros, 2011).

"Corresponding author email:_zainabelnoamani@yahoo.com

Received 4/3/2019; Accepted 30/5/2019

DOI: 10.21608/ejbo.2019.10083.1298

Edited by: Prof. Dr. Adel El-Gazzar, Faculty of Science, El-Arish University, El-Arish, N. Sinai, Egypt.

C2019 National Information and Documentation Center (NIDOC) 
A literature search revealed that palynological studies in Egypt's Paleozoic deposits have been undertaken by various researchers in different parts of the country, with studies in the Western Desert conducted by Schrank (1984, 1987), El Ghazaly \& Aly (1985), Gueinn \& Rasul (1986), El Shamma et al. (1996, 1998, 2012) and Moustafa et al. (2014); in Sinai, by Saad (1965), Omara \& Schultz (1965), Kora \& Schultz (1987), Aboul Ela (1989), Kora (1993) and Omran (1995); and in Gulf of Suez area, by Schürmann et al. (1963), Sultan (1977, 1986), Eames (1984) and Omran \& Khalifa (1988). All these studies supplied additional information that provided insights on the biostratigraphy of Egypt's Paleozoic. However, our knowledge of the Paleozoic vegetative history based on such palynological data remains limited.

Concerning the Safi Formation, which represents the uppermost Paleozoic formation in Egypt's northern Western Desert, only a few palynological investigations have been conducted on the formation's subsurface samples (e.g., El Shamma et al., 1996; Moustafa et al., 2014). Lithologically, most of the sediments near the Paleozoic/Mesozoic boundary are primarily composed of red to yellow terrestrial sandstones, which present a high degree of weathering, indicating that they were deposited in oxidizing conditions (Milani et al., 2007). This phenomenon may explain why the Safi Formation does not contain key marine zonal fossils (e.g., foraminifera, corals and conodonts) in many areas. Consequently, age dating, paleoecology and correlations rely essentially on the palynological data.

The present work is the first palynological study on the Safi Formation in the west Beni Suef Basin, Western Desert, Egypt. We propose the following objectives: (1) To define and illustrate the palynological assemblage from the Paleozoic Safi Formation's subsurface samples; (2) To reconstruct, for the first time in Egypt, the new Late Carboniferous and Early Permian paleofloral composition from the palynological record by integrating qualitative and quantitative data and the recorded palynomorph natural affinities with different botanical groups; (3) To re-evaluate the paleoecology for the reconstructed paleoflora; and (4) To correlate the paleoecology with the equivalent paleoecologies in the same phytogeoprovince.

\section{Stratigraphic setting}

The Safi Formation in the Siwa Basin was first described by Keeley (1989), it covers the northwestern part of Egypt and was observed in the Siwa-1 well $\left(29^{\circ} 07^{\prime} 18^{\prime \prime} \mathrm{N}, 23^{\circ} 25^{\prime} 50^{\prime \prime} \mathrm{E}\right)$ at a drill depth of $967-812 \mathrm{~m}$ and a thickness of $155 \mathrm{~m}$. The formation rests conformably on the Dhiffah Formation, and overlain either by Cenomanian or younger strata (Tawadros, 2011). As a result of this disconformity, the productivity of its samples varies and ranges from productive to barren according to the relative proximity of the samples to several intra-formational disconformity surfaces. This formation's lithology is composed of sandstones and siltstones along with fluviodeltaic mudstones and few marine oolitic limestones (Tawadros, 2011). Keeley (1989) assigned a Late CarboniferousEarly Permian age to the Safi Formation.

\section{Materials and Methods}

A comprehensive palynological analysis was completed for ten cutting samples picked from the Safi Formation of the Diyur-1 borehole $\left(29^{\circ}\right.$ 02 ' 32 " $\mathrm{N}$ and $29^{\circ} 01^{\prime} 57^{\prime \prime}$ E) drilled by AMOCO in 1968 in the west Beni Suef Basin northern Western Desert (Fig. 1). The investigated samples cover the depth interval from 1362 to

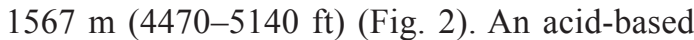
standard palynological processing technique was performed (Wood et al., 1996). Two slides from each sample were prepared using DPX as a permanent mounting medium. The slides were qualitatively and quantitatively examined microscopically under transmitted light using a DEL binocular biological compound microscope equipped with a Canon PowerShot G12 digital camera at the Botany Department, Faculty of Science, Ain Shams University. Samples barren of palynomorphs were obtained from the porous and permeable oxidized sandstones, whereas samples with exceptional productivity were only observed in three shaley intervals. The semi-quantitative data for all taxa recorded in the productive samples were expressed by counting all the palynomorph grains on one slide per sample. All materials used in the present study are housed and stored in the Palynolab, Geology Department, Faculty of Science, Cairo University. 


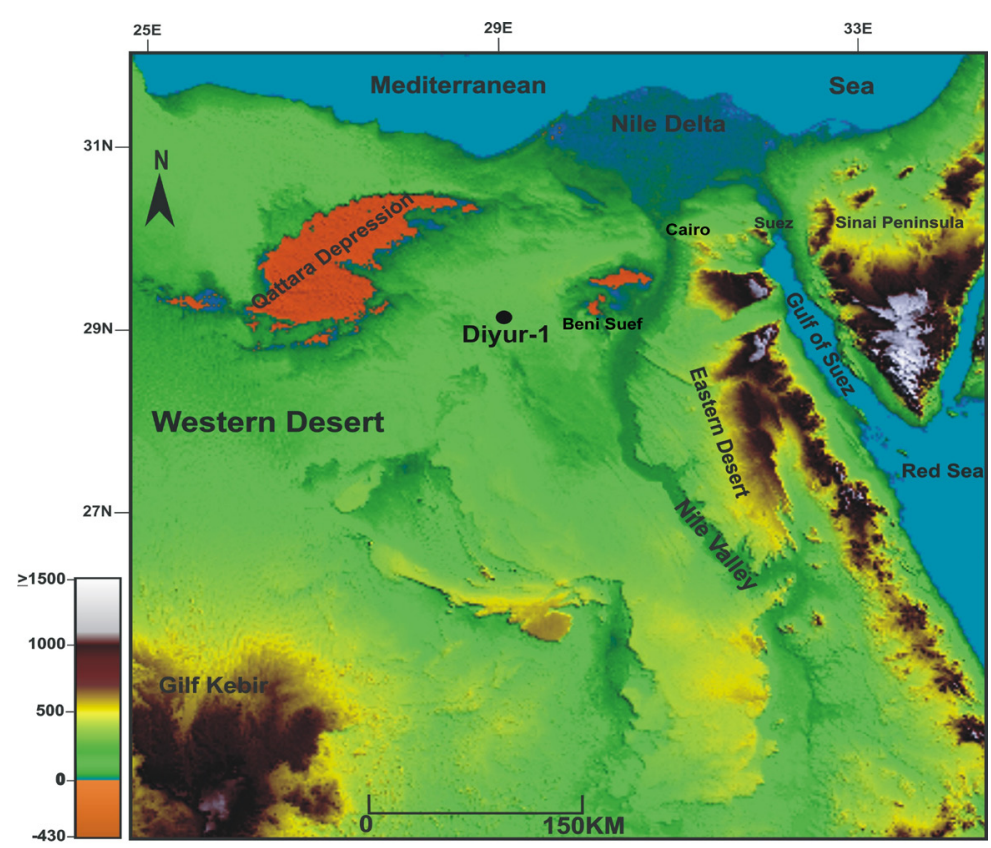

Fig. 1. Location map showing the approximate location of the Diyur-1 (D-1) borehole in the northern part of the Western Desert.

\section{Palynological Results}

Among the ten processed samples, only five productive samples were obtained from three shaley intervals at depths of $1362 \mathrm{~m}, 1433 \mathrm{~m}$, $1448 \mathrm{~m}, 1521 \mathrm{~m}$ and $1539 \mathrm{~m}$, and they yielded poor to fairly preserved diverse palynomorphs. The other five samples obtained from oxidized sandstones at depths of 1396m, 1414m, 1463m, $1494 \mathrm{~m}$ and $1567 \mathrm{~m}$ were completely barren of palynomorphs which positively indicates minimal chances for caving. The palynomorph assemblage totaled 65 species, of which 31 were pteridophyte spores (related to 20 genera) and 34 were gymnosperm pollen (related to 14 genera). None of the samples contained marine palynomorphs; only terrestrial palynomorphs were recognized.

Although the recorded "in situ" species dominated the recovered assemblage, some reworked Devonian and Mississippian species were also distinguished based on their older stratigraphic ranges, limited counts (Figs. 2, 3) and bad preservation states (Plates 1,2). Poor preservation in some cases hindered the proper identification of miospores at the species level. The presence of such reworked species will be discussed and explained in the subsequent age assignment section.
The studied lower part at depth intervals of $1539 \mathrm{~m}$ and $1521 \mathrm{~m}$ was characterized by a relatively higher diversity of palynofloral species, with a maximum of 38 species observed at $1539 \mathrm{~m}$. Monosaccate pollen was frequent, and numerous trilete and monolete spores were recovered. A few bisaccate pollen taxa appeared at this interval's base and included Illinites spp. and Protohaploxypinus spp. The middle part $(1448 \mathrm{~m}$ and $1433 \mathrm{~m})$ was characterized by a less diverse palynofloral assemblage. Monosaccate pollen was abundant and frequent and numerous trilete and monolete spores were not uncommon. A remarkable decrease in species diversity $(25$ species) was observed at the topmost of this interval's sample at $1362 \mathrm{~m}$ along with a slight increase in Cycadopites pollen (Figs. 2, 3).

The miospore genera employed in the present study are organized in Table 1 approximately according to the suprageneric classification of Dettmann (1963) as modified by Neves \& Owens (1966) and Smith \& Butterworth (1967) but his terms are omitted to save space. The botanical affinities of the encountered taxa, to reconstruct the paleovegetation, are mentioned based on the available data obtained from Ravn (1986), Balme (1995), Azcuy et al. (2002), Lindström (2003), Traverse (2007), Boardman et al. (2012), Waksmundzka (2014), Di Pasquo \& Iannuzzi (2015) and Mahesh et al. (2016). 


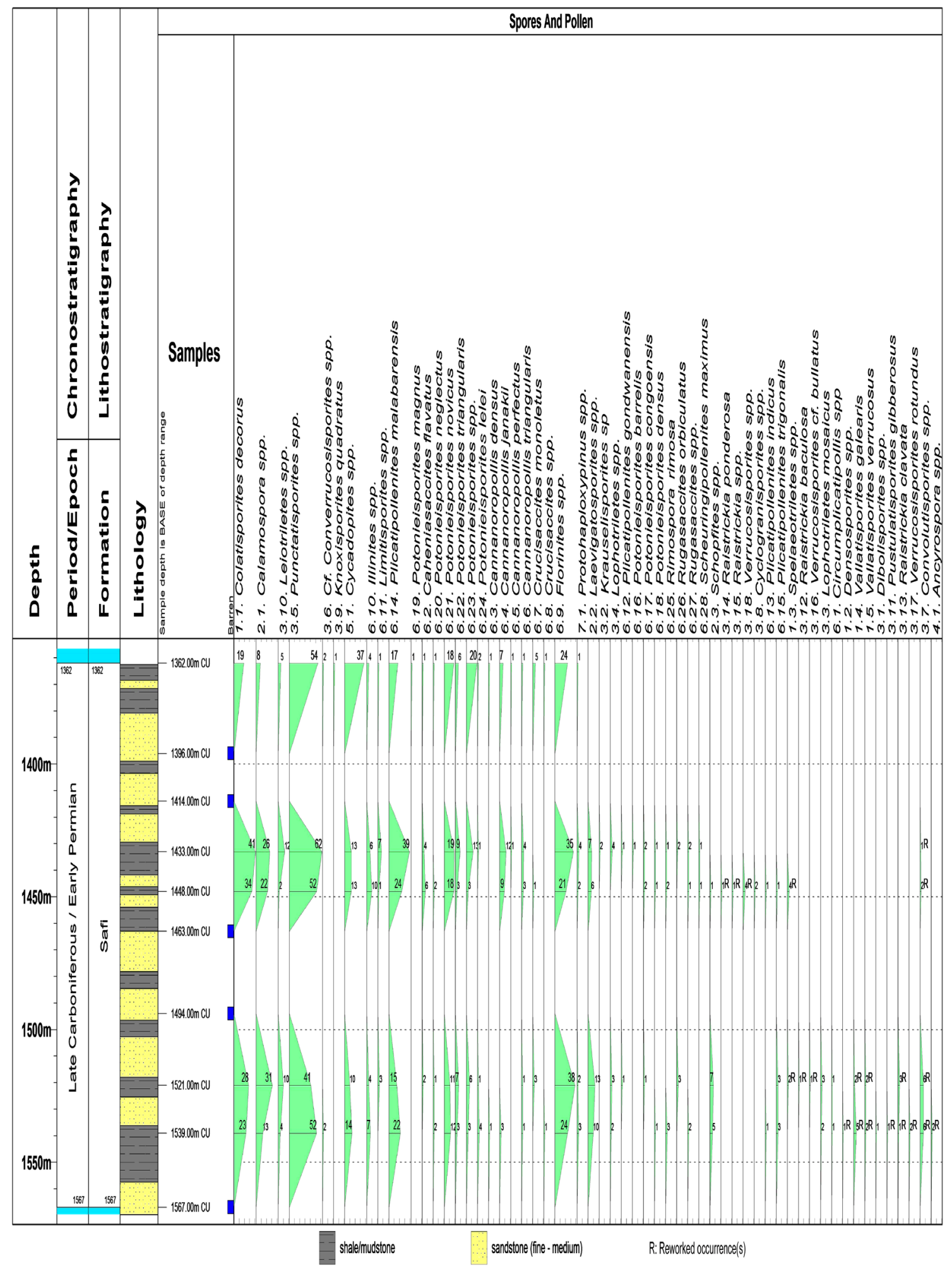

Fig. 2. Lithostratigraphical column of Safi Formation in Diyur-1 borehole showing the positions and lithologies of the studied samples [Semi-quantitative characteristics of palynomorph taxa identified in the productive samples arranged according to probable parent plant groups]. 


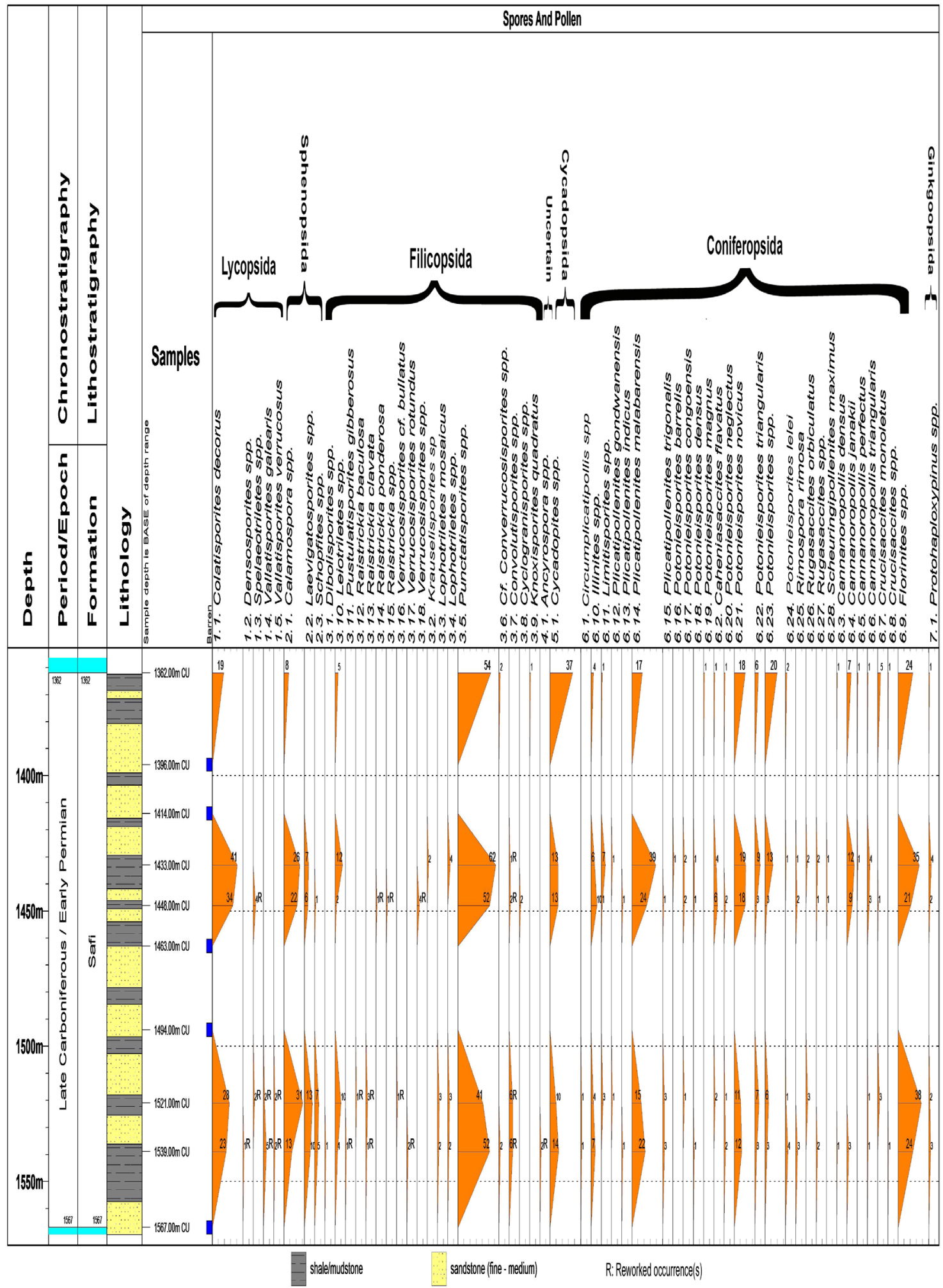

Fig. 3. Chronostratigraphic distribution of identified palynomorph species recovered from the Safi Formation in Diyur-1 borehole. 

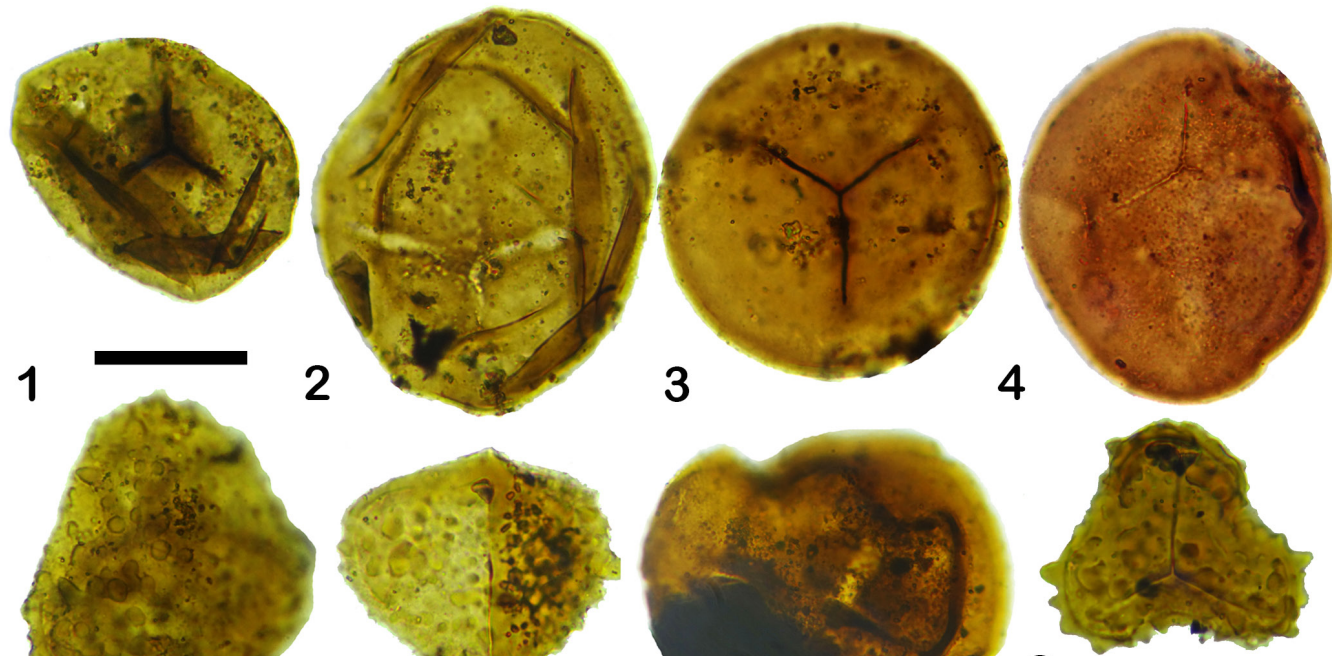

5
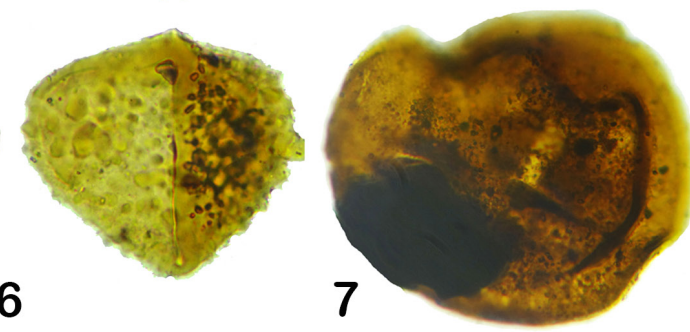

\section{8}

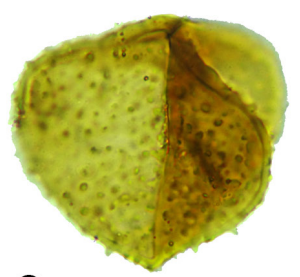

6
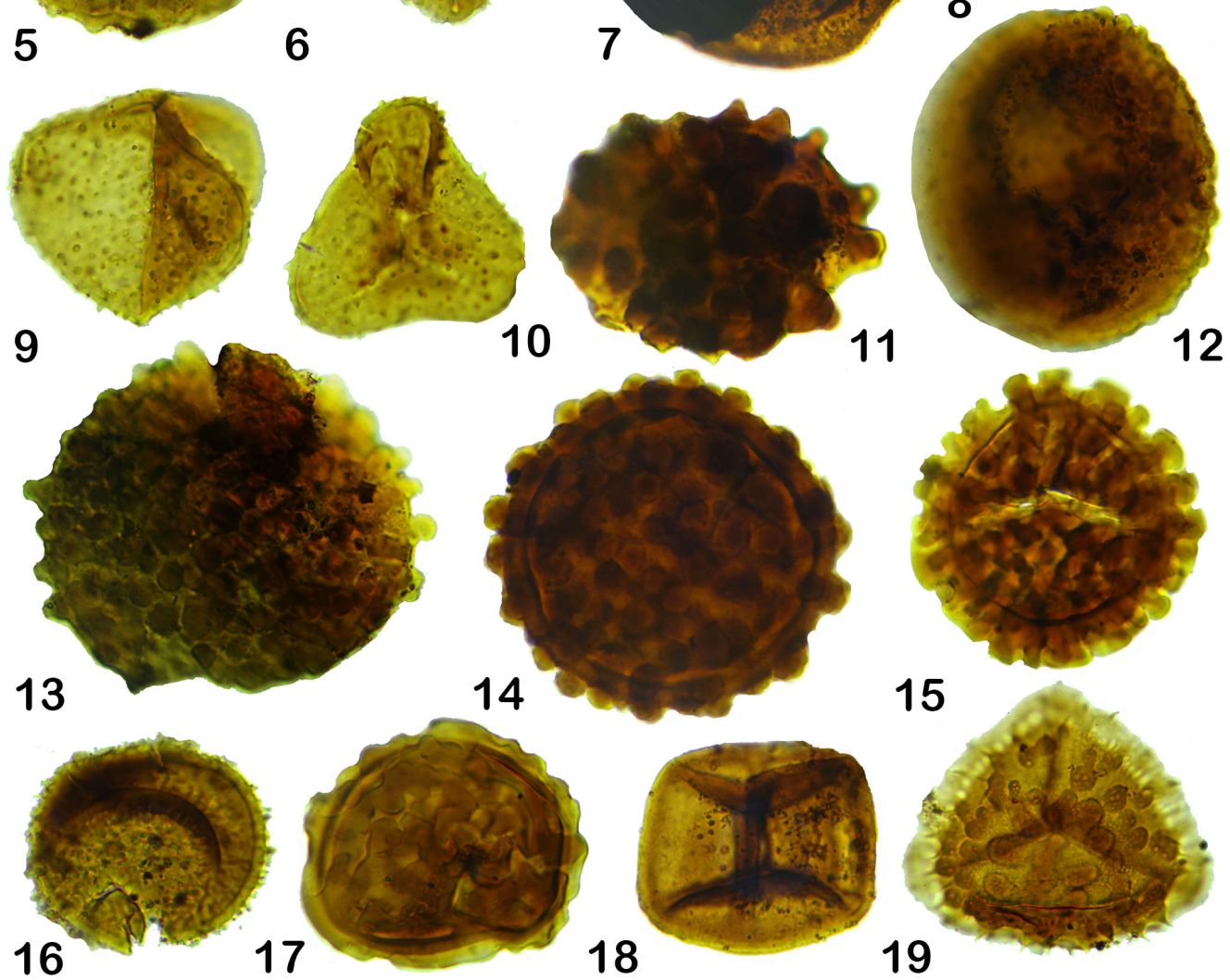

16

17

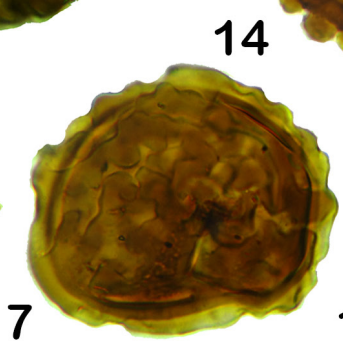

18

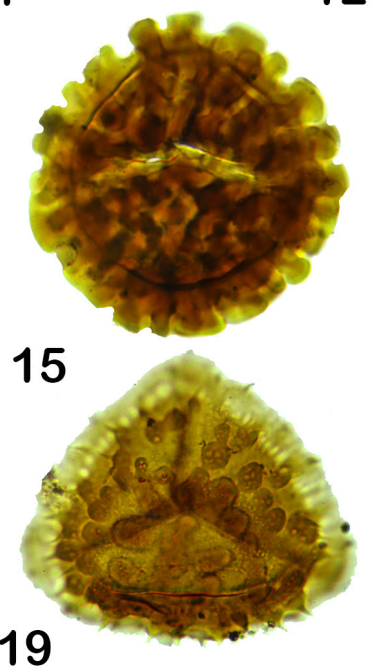

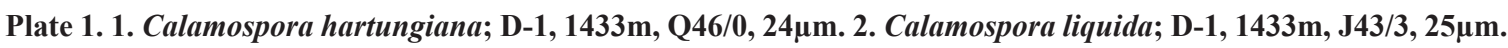



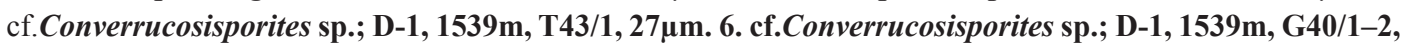

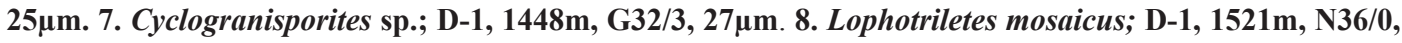



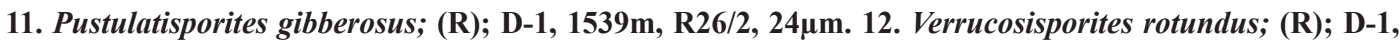

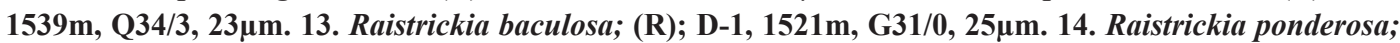

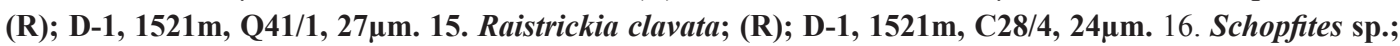

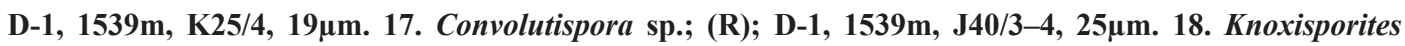

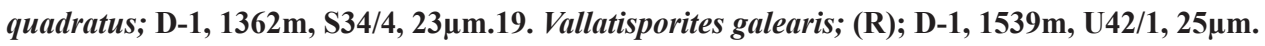




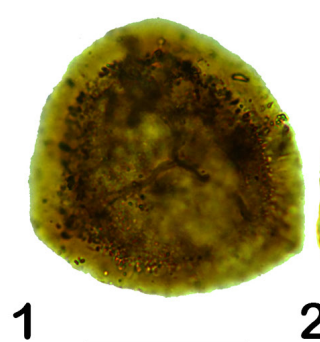

1

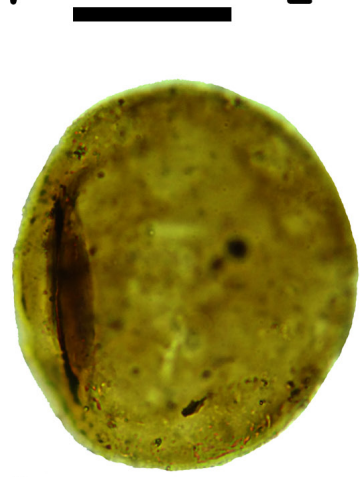

6

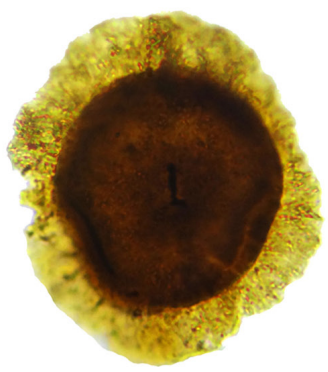

9

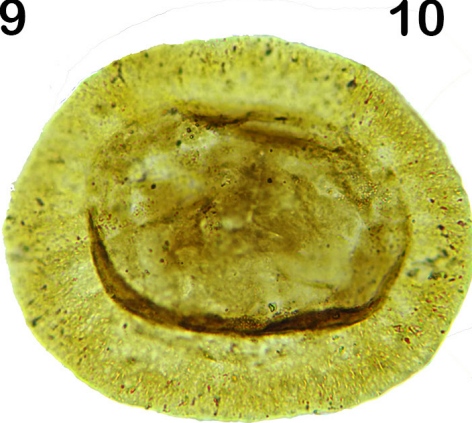

12

10

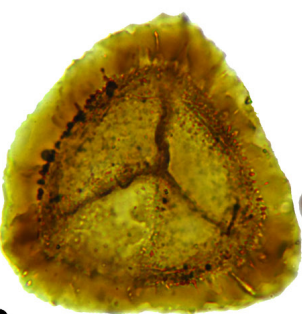

3

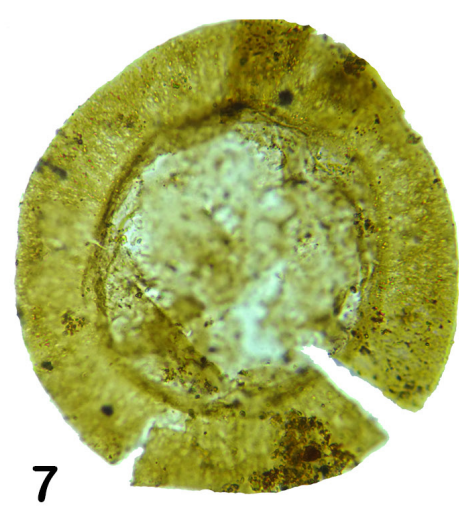

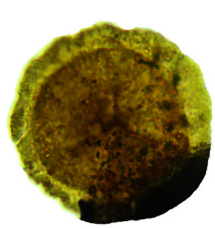

4

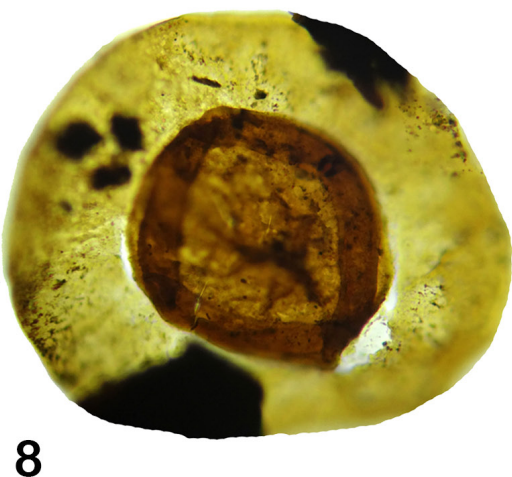

8

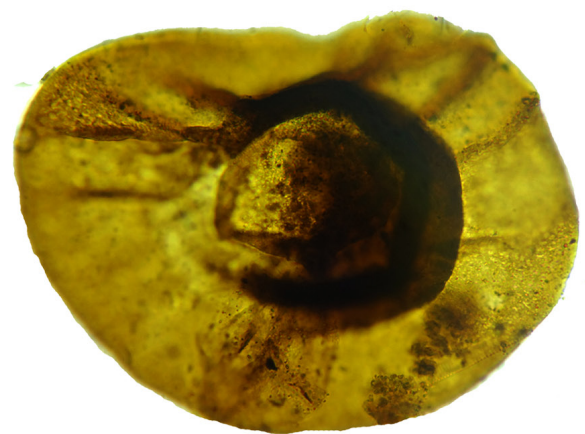

11

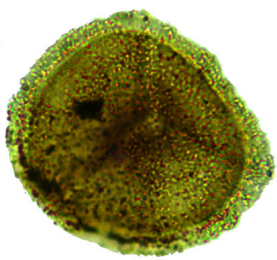

5


13

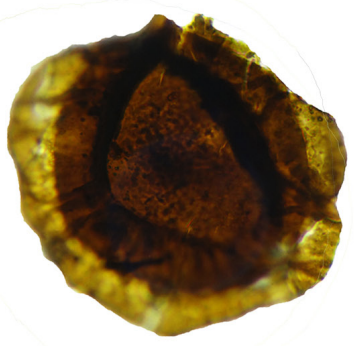

14

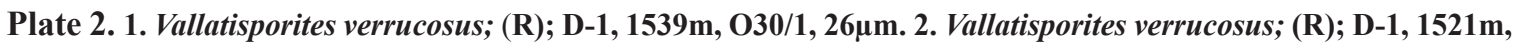
P40/1, 27 $\mu \mathrm{m}$. 3. Krauselisporites sp.; D-1, 1433m, U43/3, $22 \mu \mathrm{m}$. 4. Colatisporites decorus; D-1, 1539m, U43/1-



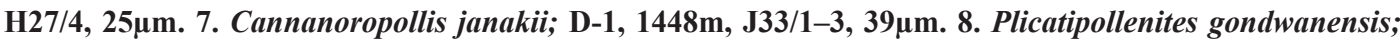



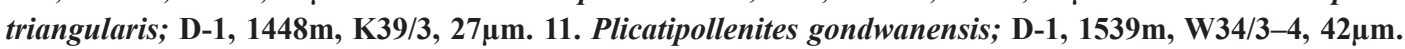

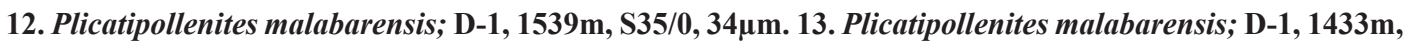

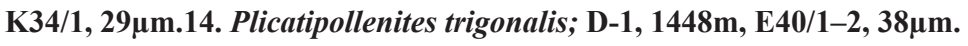


TABLE 1. List of miospore taxa recovered from Diyur-1 borehole and their possible botanical affinities.

\begin{tabular}{|c|c|c|}
\hline Miospore taxa & Possible botanical affinity & Figure \\
\hline \multicolumn{3}{|l|}{ Anteturma Sporites } \\
\hline Calamospora hartungiana & Sphenopsida & Pl. 1, Fig. 1 \\
\hline Calamospora liquida & Sphenopsida & Pl. 1, Fig. 2 \\
\hline Calamospora sp. & Sphenopsida & Not illustrated \\
\hline Leiotriletes spp. & Filicopsida & Not illustrated \\
\hline Punctatisporites gretensis & Filicopsida & Pl. 1, Fig. 3 \\
\hline Punctatisporites sp. & Filicopsida & Pl. 1, Fig. 4 \\
\hline cf. Converrucosisporites spp. & Filicopsida & Pl. 1, Figs. 5 \& 6 \\
\hline Cyclogranisporites sp. & Filicopsida & Pl. 1, Fig. 7 \\
\hline Dibolisporites sp. & Filicopsida; Cladoxylales & Not illustrated \\
\hline Lophotriletes mosaicus & Filicopsida; Botryopteridales & Pl. 1, Fig. 8 \\
\hline Lophotriletes spp. & Filicopsida; Botryopteridales & Pl. 1, Figs. $9 \& 10$ \\
\hline Pustulatisporites gibberosus & Filicopsida & Pl. 1, Fig. 11 \\
\hline Raistrickia baculosa & Filicopsida & Pl. 1, Fig. 13 \\
\hline Raistrickia clavata & Filicopsida & Pl. 1, Fig. 15 \\
\hline Raistrickia ponderosa & Filicopsida & Pl. 1, Fig. 14 \\
\hline Raistrickia spp. & Filicopsida & Not illustrated \\
\hline Schopfites sp. & Sphenopsida & Pl. 1, Fig. 16 \\
\hline Verrucosisporites cf. bullatus & Filicopsida & Not illustrated \\
\hline Verrucosisporites rotundus & Filicopsida & Pl. 1, Fig. 12 \\
\hline Verrucosisporites spp. & Filicopsida & Not illustrated \\
\hline Convolutispora spp. & Filicopsida & Pl. 1, Fig. 17 \\
\hline Knoxisporites quadratus & Filicopsida & Pl. 1, Fig. 18 \\
\hline Spelaeotriletes spp. & Lycopsida & Not illustrated \\
\hline Ancyrospora sp. & Uncertain & Not illustrated \\
\hline Densosporites sp. & Lycopsida; Pleuromeiales & Not illustrated \\
\hline Vallatisporites galearis & Lycopsida & Pl. 1, Fig. 19 \\
\hline Vallatisporites verrucosus & Lycopsida & Pl. 2, Fig. $1 \& 2$ \\
\hline Krauselisporites $\mathrm{sp}$. & Filicopsida & Pl. 2, Fig. 3 \\
\hline Colatisporites decorus & Lycopsida & Pl. 2, Figs. 4 \& 5 \\
\hline Laevigatosporites vulgaris & Sphenopsida & Pl. 2, Fig. 6 \\
\hline Laevigatosporites sp. & Sphenopsida & Not illustrated \\
\hline \multicolumn{3}{|l|}{ Anteturma Pollenites } \\
\hline Crucisaccites monoletus & Coniferopsida & Not illustrated \\
\hline Crucisaccites sp. & Coniferopsida & Not illustrated \\
\hline Florinites spp. & $\begin{array}{c}\text { Coniferopsida; Cordaitanthales; } \\
\text { Cordaitanthaceae }\end{array}$ & Not illustrated \\
\hline Cannanoropollis densus & Coniferopsida; Coniferales; Ferugliocladaceae & Pl. 2, Fig. 9 \\
\hline Cannanoropollis janakii & Coniferopsida; Coniferales; Ferugliocladaceae & Pl. 2, Fig. 7 \\
\hline Cannanoropollis perfectus & Coniferopsida; Coniferales; Ferugliocladaceae & Not illustrated \\
\hline Cannanoropollis triangularis & Coniferopsida; Coniferales; Ferugliocladaceae & P1. 2, Fig. 10 \\
\hline
\end{tabular}


TABLE 1. Cont.

\begin{tabular}{|c|c|c|}
\hline Miospore taxa & Possible botanical affinity & Figure \\
\hline Plicatipollenites gondwanensis & Coniferopsida; Coniferales & P1. 2, Figs. $8 \& 11$ \\
\hline Plicatipollenites indicus & Coniferopsida; Coniferales & Not illustrated \\
\hline Plicatipollenites malabarensis & Coniferopsida; Coniferales & Pl. 2, Figs. $12 \& 13$ \\
\hline Plicatipollenites trigonalis & Coniferopsida; Coniferales & Pl. 2, Fig. 14; Pl. 3, Fig. 2 \\
\hline Plicatipollenites sp. & Coniferopsida; Coniferales & Pl. 3, Fig. 4 \\
\hline Circumplicatipollis spp. & Coniferopsida; Coniferales & Pl. 4, Fig. 9 \\
\hline Rugasaccites orbiculatus & Coniferopsida & Not illustrated \\
\hline Rugasaccites spp. & Coniferopsida & Not illustrated \\
\hline Potonieisporites barrelis & Coniferopsida; Coniferales & Not illustrated \\
\hline Potonieisporites congoensis & Coniferopsida; Coniferales & Pl. 3, Fig. 5 \\
\hline Potonieisporites densus & Coniferopsida; Coniferales & Pl. 3, Fig. 4 \\
\hline Potonieisporites lelei & Coniferopsida; Coniferales & Pl. 3, Fig. 6 \\
\hline Potonieisporites magnus & Coniferopsida; Coniferales & Not illustrated \\
\hline Potonieisporites neglectus & Coniferopsida; Coniferales & Pl. 3, Figs. $7 \& 8$ \\
\hline Potonieisporites novicus & Coniferopsida; Coniferales & Pl. 3, Fig. 9 \\
\hline cf. Potonieisporites novicus & Coniferopsida; Coniferales & Not illustrated \\
\hline Potonieisporites triangulatus & Coniferopsida; Coniferales & Pl. 3, Fig. 3; Pl. 4, Fig. 1 \\
\hline Potonieisporites sp. & Coniferopsida; Coniferales & Pl. 4, Fig. 2 \\
\hline Rimospora rimosa & Coniferopsida & Pl. 4, Fig. 3 \\
\hline Caheniasaccites flavatus & Coniferopsida; Coniferales & Pl. 4, Fig. 5 \\
\hline Limitisporites $\mathrm{cf}$. rectus & Coniferopsida; Coniferales & Pl. 4, Fig. 7 \\
\hline Limitisporites spp. & Coniferopsida; Coniferales & Pl. 4, Fig. 6 \\
\hline Illinites spp. & Coniferopsida; Coniferales & Not illustrated \\
\hline Protohaploxypinus amplus & Ginkgoopsida; Glossopteridales/Peltaspermales & Pl. 4, Fig. 10 \\
\hline Protohaploxypinus spp. & Ginkgoopsida; Glossopteridales/Peltaspermales & Not illustrated \\
\hline Cycadopites spp. & Cycadopsida; Bennettitales/Cycadales & Not illustrated \\
\hline Scheuringipollenites maximus & Coniferopsida & Pl. 4, Figs. 8,10 \\
\hline
\end{tabular}




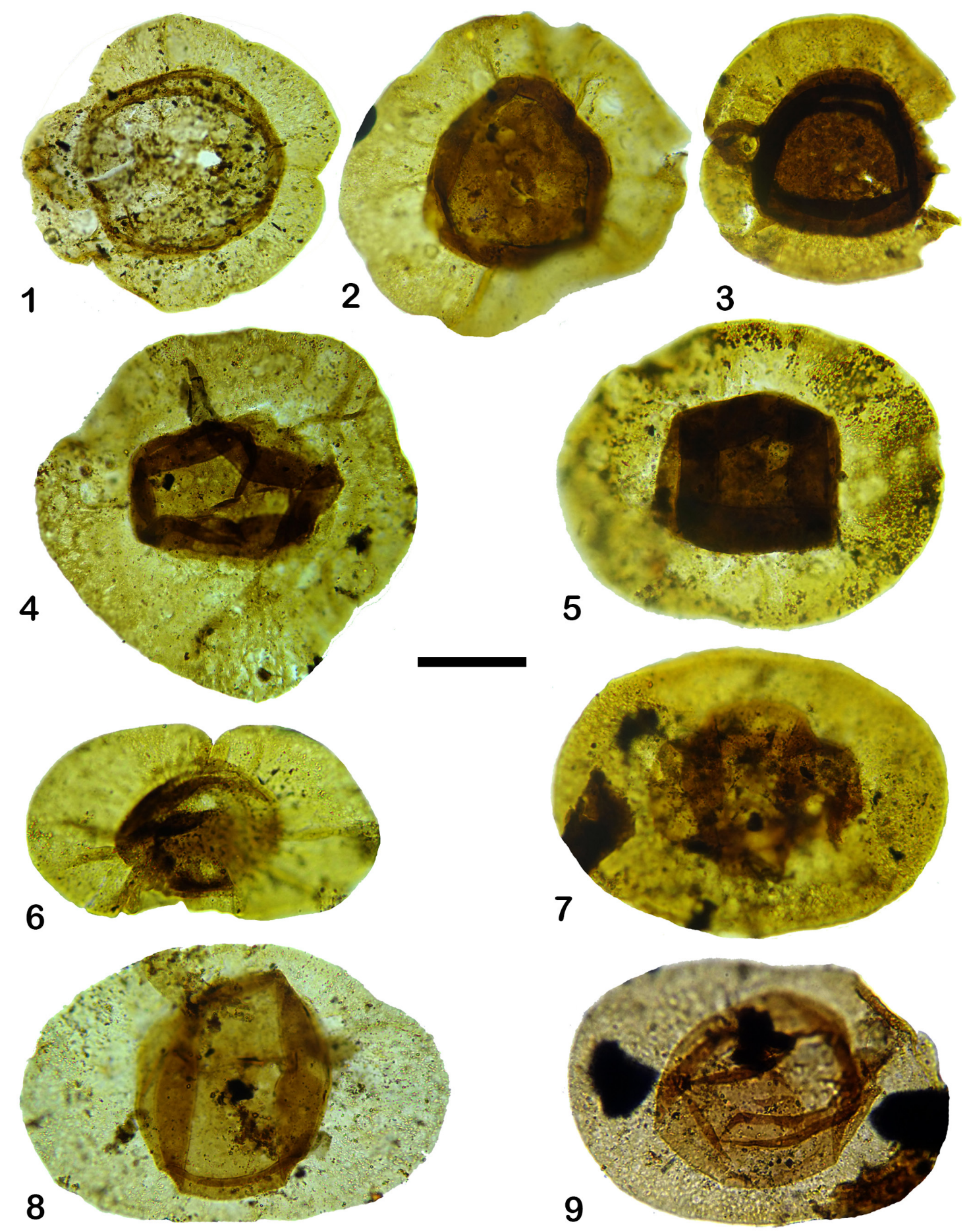

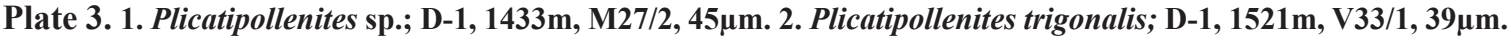
3. Potonieisporites triangulates; D-1, 1521m, W26/3-4, 42 $\mu \mathrm{m}$. 4. Potonieisporites densus; D-1, 1433m, Q26/2,

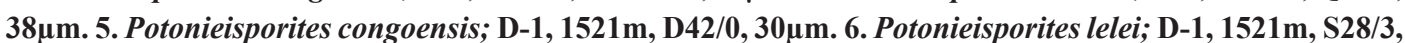

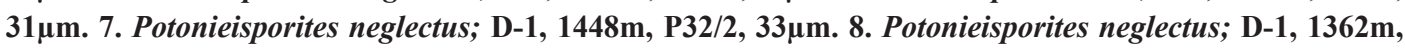

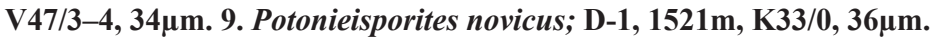




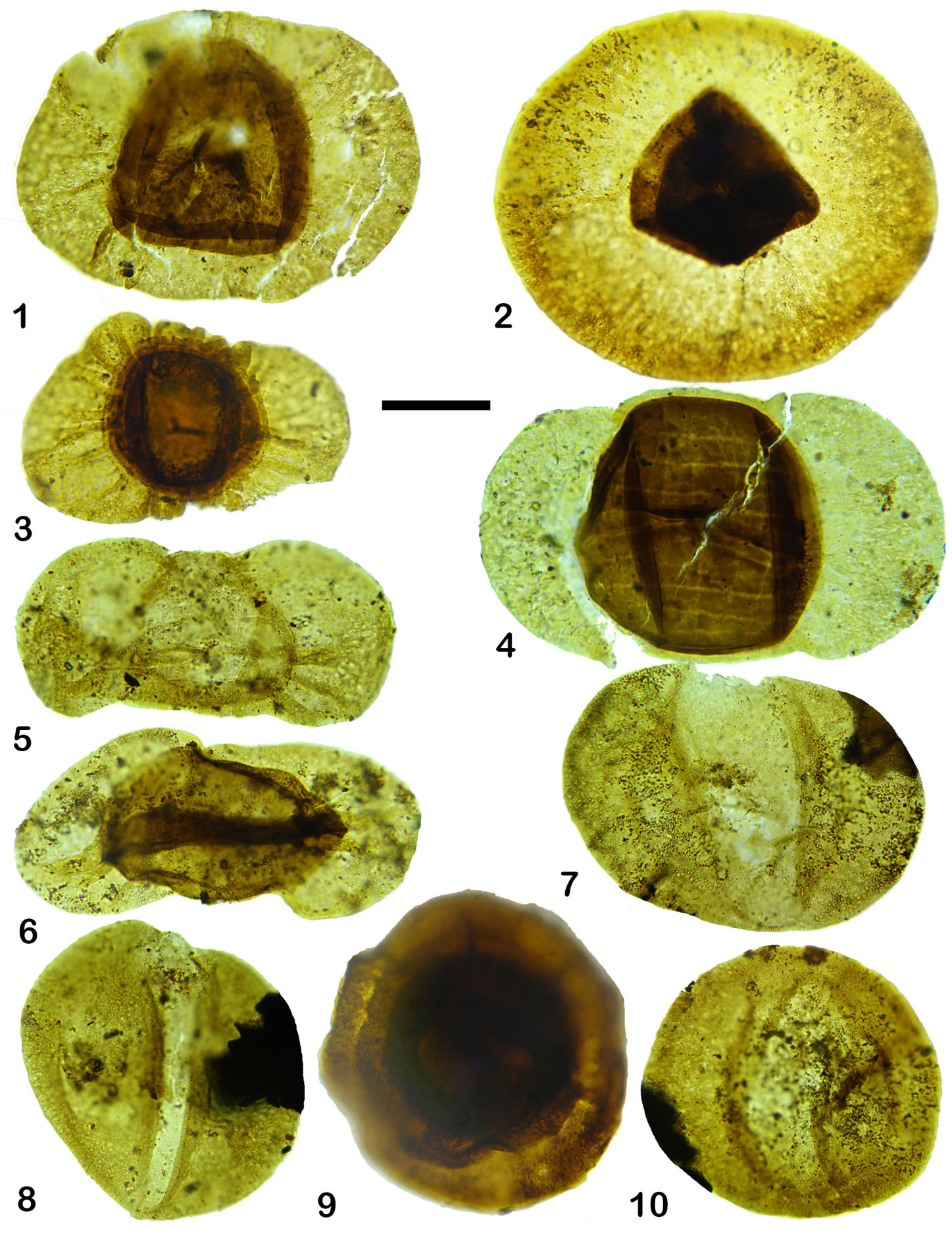

Plate 4. 1. Potonieisporites triangulates; D-1, 1521m, F26/1-3, 33 $\mu \mathrm{m}$. 2. Potonieisporites sp.; D-1, 1539m, P25/4, $38 \mu \mathrm{m}$. 3. Rimospora rimosa; D-1, 1521 m, S28/3, 31 $\mu \mathrm{m}$. 4. Protohaploxypinus amplus; D-1, 1433m, E28/1,

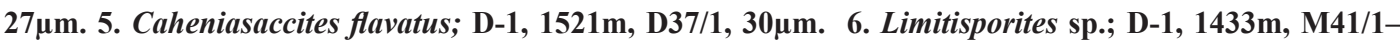

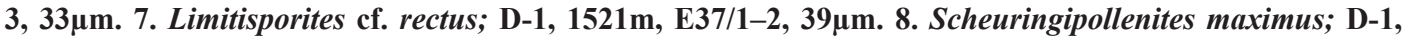

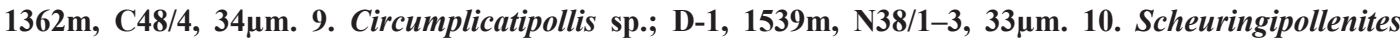
maximus; D-1, 1433m, P28/1, 38 $\mu \mathrm{m}$. 
Age assignment of the present palynoassemblage

The present age assignment critically considers the known stratigraphical ranges of all recorded in situ as well as the reworked taxa and the potential influence of their ranges on the interpretation of the biostratigraphy of the studied interval. The studied section can be divided into two main intervals based on a careful qualitative and quantitative study of the vertical distribution of the recovered diagnostic Late Devonian-Early Carboniferous (Mississippian) as well as the Late Carboniferous, Pennsylvanian (WestphalianStephanian)-Early Permian taxa and the analysis of their stratigraphic distribution counts in the studied samples relative to each other. In addition, the impact of potential downhole caving contamination as well as the completely barren samples and their positions in the studied interval are significantly considered. The monosaccates are long ranged taxa in Carboniferous, so it is difficult to use them solely for biostratigraphic purposes unless they are supported by other diagnostic spores, or pollen species more constrained in age.

Upper interval (Samples 1362 and 1433m)

The present palynological assemblage recorded in the interval $1362-1433 \mathrm{~m}$ of the Diyur-1 well is characterized by the common occurrence of the monosaccate pollen Potonieis porites, Plicatipollenites and Florinites species. In addition, Punctatisporites and Cycadopites species associated with Colatisporites decorus, Limitisporites, Illinites and Cannanoropollis taxa are common. Finally, a few noteworthy occurrences of the striated bisaccate pollen taxa of Protohaploxypinus were observed (Figs. 2, 3).

Although saccate gymnosperm pollens are generally known to be stratigraphically long ranging and have relatively poor biostratigraphic utility, many researchers have focused on these species because they occur abundantly and significantly in non-negligible records that have been effectively used by many authors researching Gondwana (Brazil, Libya, etc., as addressed in the sections focused on regional palynostratigraphy and correlations) to illustrate the sporomorph biostratigraphy of the late Pennsylvanian (Westphalian - Stephanian). Additionally, the significant presence of the taeniate bisaccates, which are unlikely to be older than the latest Carboniferous, represents an age-control palynoevent for the studied interval (G. Clayton, pers. comm., September 2017). The recovered assemblage contains common monosaccate, taeniate bisaccate and non-taeniate bisaccate pollen. Based on palynological events in Western Europe and North America (Clayton et al., 1977; Owens, 1996), the appearance of taeniate pollen indicates an age not older than the Stephanian.

The dominance of monosaccate pollen grains (Potonieisporites, Plicatipollenites and Florinites) combined with the low frequency of taeniate pollen grains (Protohaploxypinus) confirms a late Pennsylvanian age (Westphalian-Stephanian; 306.5-299 Ma) as documented in various Gondwana basins in Brazil (Souza 2006; Souza et al. 2015), Libya (Brugman et al., 1988; Loboziak \& Clayton, 1988), Saudi Arabia and Oman (Love, 1994; Owens \& Turner, 1995) and Australia (Kemp et al., 1977). Taeniate pollen grains first appear in the Moscovian (Westphalian), thus confirming a post-Westphalian age (e.g., Inosova et al., 1976; Souza, 2006; Souza et al., 2015), and this pollen has shown a continuous abundant and diverse presence since the Asselian (Early Permian) of both the Euramerican and Gondwanan provinces (Inosova et al., 1976; Kemp et al., 1977). A similar palynoevent as the monosaccate acme was recorded in Oman, Yemen and Pakistan during the Late Carboniferous (Kasimovian-Gzhelian; $307-$ 298.9 Ma) (Stephenson et al., 2003; Stephenson, 2006; Jan \& Stephenson, 2011; Stephenson et al., 2013).

The limited counts and restricted presence of taeniate (striate) bisaccate and nontaeniate bisaccate pollen, such as Illinites, Protohaploxypinus and Limitisporites, in the present assemblage in addition to the common occurrence of Cycadopites pollen taxa limit the age to the Asselian (Early Permian). Additionally, the present assemblage lacks the monosaccate Samoilovitchi saccites and Divarisaccus pollen grains, taeniate bisaccate Corisaccites and Hamiapollenites genera, taeniate non-saccate Vittatina and Costapollenites genera and the miospore Indotriradites, Columnisporites and Maculatasporites taxa that characterize the Sakmarian-Artinskian in nearby northeast Libya (Brugman et al., 1985). Such absences verify an age of at least the Asselian for the uppermost part of the studied interval herein. 
As confirmatory evidence for the StephanianAsselian age, a strikingly similar palynological event and comparable palynoassemblage was recorded in the close northeastern section of Libya by Brugman et al.(1985), thus showing a dominance of monosaccate pollen and low frequencies of spores, taeniate (striate) and nontaeniate bisaccate pollen grains, and dated the assemblage as the Ghzelian-Asselian. Within the Libyan assemblage, three characteristic elements could be recognized: 1) Monosaccate pollen genera, such as Potonieisporites; 2) Taeniate (striate) bisaccate pollen taxa of Illinites; and 3) Nontaeniate bisaccate pollen, such as Limitisporites. The present assemblage is similar to that recorded in Libya because all the taxa mentioned in the Libyan assemblage are also recorded in the present assemblage.

\section{Lower interval (Samples 1448, 1521 and $1539 m)$}

Infrequent occurrences of Late Devonian and Early Carboniferous (Tournaisian-early Visean) markers were recovered in low counts (five grains at maximum) in the samples of the lower interval. These markers include Ancrospora sp. recorded from the Upper Devonian of Libya, North Africa and Saudi Arabia (Streel et al., 1988; Loboziak \& Streel, 1989; Loboziak, 2000); Vallatisporites spp. recorded from the Upper Devonian (Streel and Loboziak, 1996); and Verrucosisporites bullatus recorded from the Upper Devonian of North Africa and Libya (Paris et al., 1985; Streel et al., 1988; Loboziak et al., 1992; Grignani et al., 1992). Some significant Early Carboniferous taxa include Spelaeotriletes, Vallatisporites, Convolutisporites, Verrucosisporites, Raistrickia species beside Colatisporites decorus and Pustulatisporites gibberosus were recorded from the Tournaisianearly Visean of Gulf of Suez, Egypt (Kora \& Schultz, 1987); Libya, the Algerian Sahara, North Africa (Clayton \& Loboziak, 1985; Loboziak \& Clayton, 1988; Grignani et al., 1992; Attar et al., 1980); Saudi Arabia (Owens et al., 2000) and globally (Playford \& McGregor, 1993).

All the previous mentioned assemblages in the upper interval $(1362-1433 \mathrm{~m})$ are also present in this interval (1448-1539m) which may be due to caving process, although the few occurrences of Vallatisporites, Raistrickia and Verrucosisporites markers may suggest a Tournaisian-early Visean age for the lower interval. Thus, one of the possible scenarios is thatthe studied interval may have an
Early Carboniferous section (Tournaisian-Visean) which includes at least the samples at $1448 \mathrm{~m}$, $1521 \mathrm{~m}$ and $1539 \mathrm{~m}$. This is overlain by a Late Carboniferous interval which includes at least the sample $1362 \mathrm{~m}$. But, the in situ occurrences of the Late Carboniferous taxa previously mentioned in the upper interval (1362-1433m) could not be believed to be caved in the lower interval (1448$1539 \mathrm{~m})$. However, a caving process likely did not cause the assemblage's persistent occurrence for two reasons. First, the quantitative vertical stratigraphic abundances chart (Figs. 2, 3) shows that certain taxa (e.g. Florinites spp.) are present in even higher counts compared with that of the upper interval (1362-1433m). This finding indicates that these taxa are not caved and are certainly in situ in the lower and upper intervals as well. Second, if all the taxa in the lower interval (1448-1539m) were caved from the upper Late Carboniferous interval (1362-1433m), why were form occurrences and counts not observed in the barren samples $1463 \mathrm{~m}$ and $1494 \mathrm{~m}$ ? The samples completely lacked these taxa, which indicated that these taxa did not suffer from the same consistent caving process; thus, a caving process did not occur.

The proved few in situ occurrences of Crucisaccites monoletusand Protohaploxypinus species in most of the studied samples confirm Late Carboniferous age for both the upper and lower intervals rather than Early Carboniferous for the lower one. The few infrequent occurrences of the Late Devonian-Early Carboniferous recorded especially in the lower interval (1448-1539m) beside their remarkable bad preservation may support that these taxa are not in situ but reworked forms.

Moreover, the concurrence of the Devonian markers in the same stratigraphic level/horizon with the previously mentioned Tournaisian-early Visean taxa in the lower interval (1448-1539m) confirm that all Devonian and Early Carboniferous taxa were reworked together and not in situ. Such a scenario, which indicates that any Devonian or older and Early Carboniferous specimens may have been reworked into the Late Carboniferous (or younger) deposits, could be believed with confidence. In particular, this situation is a commonly recorded phenomenon in North Africa and the Middle East, where Late Carboniferous assemblages often contain large numbers of reworked Late Devonian and Early Carboniferous specimens (G. Clayton, pers. comm.,September 2017). 


\section{Paleovegetation reconstruction}

Despite the different strategies for the preservation of plant macro- and microfossils, the combined and compared data from both sources provide a robust reflection of the floristic trends and paleoclimate interpretation during the studied interval.

Based on the identified microflora's paleobotanical affinities and regardless of the minor miospore genera with doubtful botanical affinity, we assume that the paleovegetation of the present palynoassemblage consisted of six vascular plant Linnaean classes that are entirely distinct from those that constitute most of the modern ecosystem biomass.

In order of dominance, Coniferopsida represents the most abundant group (34\%), followed by Filicopsida (30\%), Lycopsida (14\%), Sphenopsida (13\%), Cycadopsida (8\%) and Ginkgoopsida (1\%). Of the Coniferopsida, the cordaitanthalean and coniferalean monosaccate pollen genera Florinites, Cannanoropollis, Plicatipollenites, and Potonieisporites are the most abundant. Among Filicopsida, marattialean ferns are the most abundant and are represented predominantly by Punctatisporites taxa. Colatisporites is the most abundant genus among Lycopsida. Within the Sphenopsida, the calamitalean genus Calamospora is the most predominant. Cycadopsida is represented by only one genus, Cycadopites. Ginkgoopsida is represented predominantly by the striate bisaccate Glossopterid pollen taxonProtohaploxypinus (see Fig. 2).

Egypt's macroflora during the Late Carboniferous and Early Permian has been studied by many authors (Ball, 1916; Barakat et al., 1984; Lejal-Nicol, 1987, 1990; El Saadawi et al., 2003; Darwish \& El Safori, 2016), who reported a total of 49 morphotaxa from different outcrops accounting for ten species of Lycopsida (related to five genera), 13 species of Sphenopsida (related to six genera), six species of Filicopsida (related to four genera), one species of Cycadopsida, six species of Ginkgoopsida (related to four genera) and13 species of Coniferopsida (related to six genera) (see Table 2 for taxa names, ages and localities).

The present palynofloral assemblage has been compared with the known macrofloral remains described from the Egyptian outcrops during the Late Carboniferous and Early Permian age. This comparison has revealed considerable consistency in the parent plant groups' representation. The same classes were recorded in both assemblages. The other consensus is the dominance of Coniferopsida in association with other plant groups during the Late Carboniferous and Early Permian interval.

\section{Paleoecological implications}

Under the influence of glaciations that characterized Earth's history close to the end of the Late Carboniferous, a cold climate prevailed over Gondwana throughout the Late Carboniferous and Early Permian (Di Michele et al., 1996, 2005). According to the obtained palynological data, we can conclude that two paleofloral types occurred in the Beni Suef Basin during the Late Carboniferous and Early Permian: a lowland paleoflora that was represented by a cold climate wetland fern community co-occurring frequently with Lycopsida, Sphenopsida and Cycadopsida vegetation; and an upland paleoflora that was dominated by a primitive group of conifers that produce monosaccate pollen (Cordaitanthales and Coniferales). This group mainly occupied relatively arid highlands because they have a unique moisture-independent reproductive strategy that enables them to tolerate the physiological drought that occurred in moisturedeficient or well-drained environments (Stephenson \& Osterloff, 2002; Stephenson et al., 2005; Souza et al., 2015). In the present study, the upland flora's percentage increased compared with that of the lowland flora. This finding could be attributed to a lacustrine flooding resulting from minor deglaciation events that could decrease/prevent the lowland spore-producing plants' persistence, thereby increasing the upland flora's representation (Stephenson \& Osterloff, 2002). This finding is consistent with the results obtained from various Gondwanan basins by Azcuy (1979), Playford \& Dino (2000) and Souza et al. (2015) for South America; by Tiwari \& Tripathi (1992) and Srivastava \& Agnihotri (2009) for India; by Lindström (1995) for Antarctica; and by Balme (1980), Backhouse (1991) and Jones \& Truswell (1992) for Australia (Souza et al., 2015 and references therein). 
TABLE 2. Synoptic listing of the macrofossil taxa recognized, up till now, from Late Carboniferous and Early Permian outcrops of Egypt (Based on: 1. Ball, 1916; 2. Barakat et al., 1984; 3. Lejal-Nicol, 1987; 4. Lejal-Nicol, 1990; 5. El Saadawi et al., 2003; 6. Darwish \& ElSafori, 2016) [SWD= South Western Desert, NED= North Eastern Desert].

\begin{tabular}{|c|c|c|c|c|c|c|c|c|c|c|c|}
\hline \multirow[b]{3}{*}{ Parent plant group/Morphotaxa } & \multirow{3}{*}{$\begin{array}{l}\text { Plant } \\
\text { organ }\end{array}$} & \multicolumn{2}{|c|}{ Age } & \multicolumn{7}{|c|}{ Localities } & \multirow{3}{*}{ 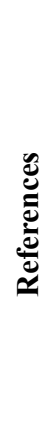 } \\
\hline & & \multirow{2}{*}{ 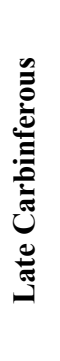 } & \multirow{2}{*}{ 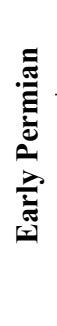 } & \multicolumn{2}{|c|}{ SWD } & \multicolumn{4}{|c|}{ NED } & \multirow[b]{2}{*}{$\begin{array}{l}\bar{\sigma} \\
\overline{\tilde{E}} \\
\overline{\tilde{\sigma}} \\
\overline{\tilde{E}}\end{array}$} & \\
\hline & & & & 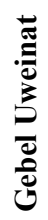 & 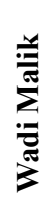 & 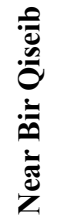 & 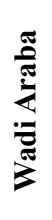 & 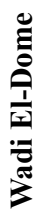 & 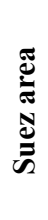 & & \\
\hline
\end{tabular}

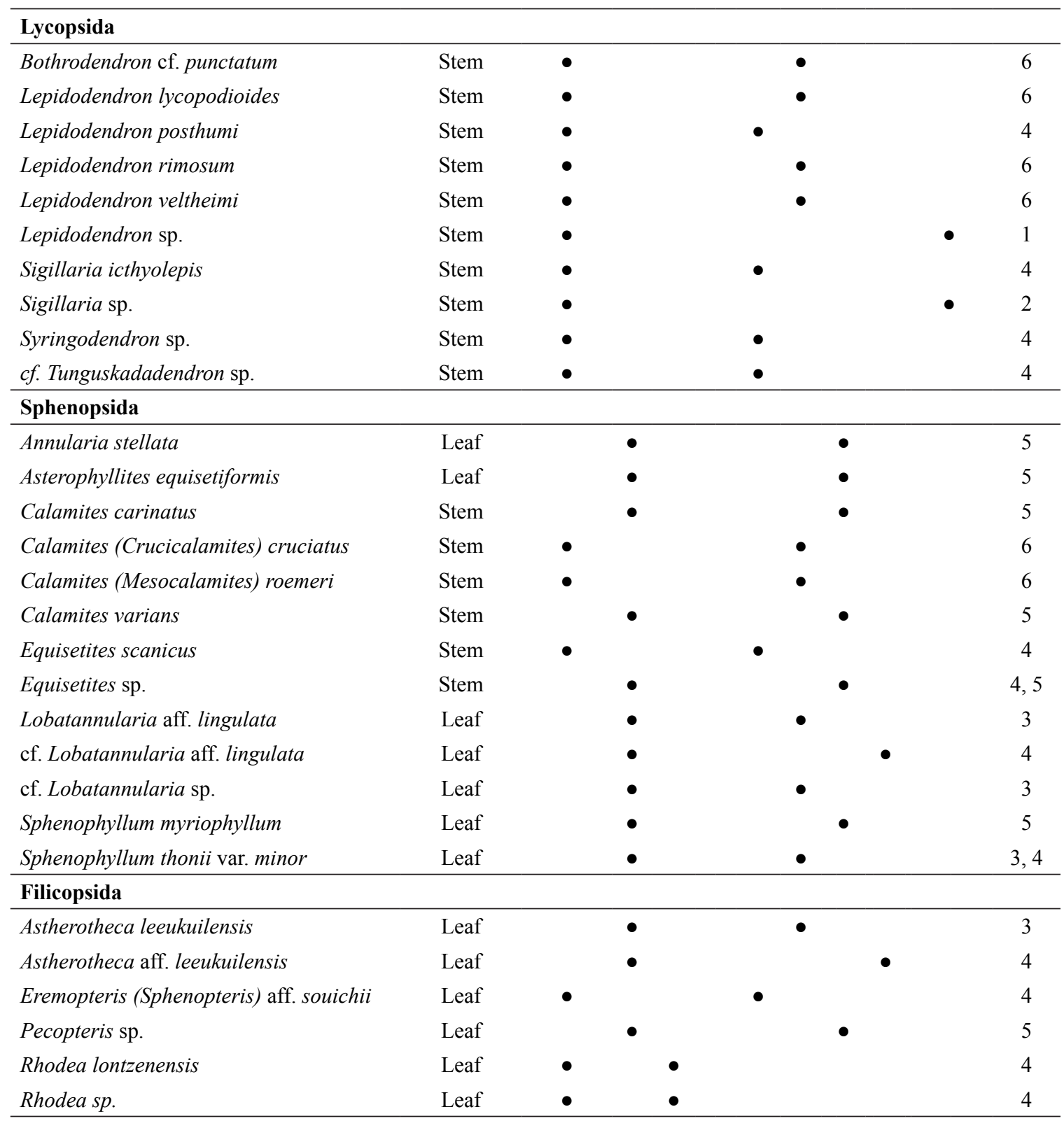


TABLE 2. Cont.

\begin{tabular}{|c|c|c|c|c|c|c|c|c|c|c|c|}
\hline \multirow[b]{3}{*}{ Parent plant group/Morphotaxa } & \multirow{3}{*}{$\begin{array}{l}\text { Plant } \\
\text { organ }\end{array}$} & \multicolumn{2}{|c|}{ Age } & \multicolumn{7}{|c|}{ Localities } & \multirow{3}{*}{ 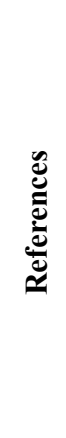 } \\
\hline & & \multirow{2}{*}{ 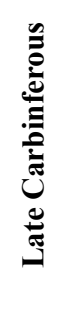 } & \multirow{2}{*}{ 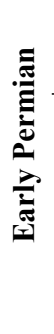 } & \multicolumn{2}{|c|}{ SWD } & \multicolumn{3}{|c|}{ NED } & \multirow{2}{*}{\multicolumn{2}{|c|}{ 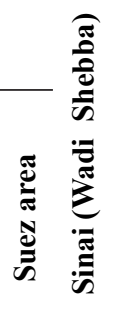 }} & \\
\hline & & & & 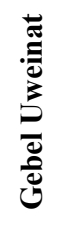 & & 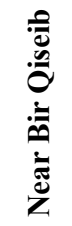 & $\begin{array}{l}\frac{\pi}{\pi} \\
\frac{\pi}{\pi} \\
:= \\
\frac{\pi}{\pi}\end{array}$ & 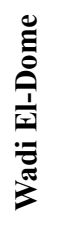 & & & \\
\hline \multicolumn{12}{|l|}{ Cycadopsida } \\
\hline Callipteridum sp. & Ovule & $\bullet$ & & & & $\bullet$ & & & & & 6 \\
\hline \multicolumn{12}{|l|}{ Coniferopsida } \\
\hline Artisia approximata & Stem & $\bullet$ & & & & $\bullet$ & & & & & 6 \\
\hline ?Artisia transversa & Stem & $\bullet$ & & & & $\bullet$ & & & & & 6 \\
\hline cf. Artisia sp.? & Stem & $\bullet$ & & $\bullet$ & & & & & & & 4 \\
\hline Cordaites angulostriatus & Leaf & $\bullet$ & & $\bullet$ & & & & & & & 4 \\
\hline cf. Cordaites regularis & Leaf & $\bullet$ & & & & & & & & & 3 \\
\hline Cordaites spp. & Leaf & $\bullet$ & $\bullet$ & & & $\bullet$ & $\bullet$ & & & & 5,6 \\
\hline Cordaitanthus aff. duquesnensis & Cone & & $\bullet$ & & & $\bullet$ & & $\bullet$ & & & 3,4 \\
\hline Dorycordaites sp. & Leaf & & $\bullet$ & & & $\bullet$ & & & & & 3 \\
\hline Lebachia hypnoides & Leaf & $\bullet$ & & & $\bullet$ & & & & & & 4 \\
\hline Lebachia aff. hypnoides & Leaf & & $\bullet$ & & & $\bullet$ & & $\bullet$ & & & 3,4 \\
\hline Walchia sp. & Leaf & $\bullet$ & & & $\bullet$ & & & & & & 4 \\
\hline \multicolumn{12}{|l|}{ Ginkgoopsida } \\
\hline Autunia conferta var. vulgaris & Leaf & & $\bullet$ & & & & & $\bullet$ & & & 3 \\
\hline Callipteris conferta var. vulgaris & Leaf & & $\bullet$ & & & & & $\bullet$ & & & 4 \\
\hline Gangamopteris sp. & Leaf & & $\bullet$ & & & $\bullet$ & & & & & 3 \\
\hline cf. Gangamopteris sp. & Leaf & & $\bullet$ & & & & & $\bullet$ & & & 4 \\
\hline Pachypteris (Thinnfeldia) aff. decurrens & Leaf & & $\bullet$ & & & $\bullet$ & & & & & 3 \\
\hline Pachypteris (Thinnfeldia) sp. & Leaf & & $\bullet$ & & & & & $\bullet$ & & & 4 \\
\hline
\end{tabular}

However, the percentage of Cycadopsida in the uppermost sample from the horizon at $1362 \mathrm{~m}$ increased slightly compared with that of the deeper samples (from $4 \%$ to $16 \%$ ). This result could indicate a slight climate amelioration toward warmer, wetter conditions, which began to occur at the end of the Early Permian. At that time, the vegetation was ready to change from a glacial fern flora to the warmer dominant colpate pollen-producing and lycopsid lowland flora observed during the Late Permian. However, no marked change was observed in this sample's upland paleoflora.
The absence of any marine palynomorphs in the analyzed interval confirmed that the studied sequence's sedimentary settings were of a continental/terrestrial nature. This interpretation could also be supported by the lithological analysis, which is interpreted as representing a fining upward cycle resulting from decreased energy, thus characterizing an event to the front of the glacial retreat and subsequent fluvial flooding.

Paleobiogeographic implications

Compared with the Early Paleozoic, the Late 
Paleozoic phytogeography was considerably more complicated, which was partly because more taxa had evolved, thus leading to greater floral heterogeneity. Similar to modern taxa, this heterogeneity may be attributed to complex interrelated factors, such as evolution, migration, climatic patterns, physical atmospheric and oceanic circulation patterns and tectonic movements (Wnuk, 1996). Of the Late Paleozoic periods, the Late Carboniferous/Early Permian interval is characterized by a regional differentiation of world flora that show a degree of divergence unrivaled in any other period with the possible exception of the latest Cenozoic, which may be relevant to continental drift and contemporaneous pole position (Chaloner \& Lacey, 1973). According to Wnuk (1996), four major paleogeographic provinces can be recognized during this interval: the Angaran, Euramerican, Cathaysian, and Gondwanan provinces.

The present palynological data are closely correlated with the coeval microflora in the Gondwana floral province, which encompasses present-day Africa, Madagascar, South America, India, Arabia, Antarctica, Australia, and New
Zealand. This correlation is observed in the high representation of the bilaterally or radially symmetrical monosaccate gymnosperm pollen genera Caheniasaccites, Cannanoropollis, Crucisaccites, Plicatipollenites and Potonieisporites. This comparison indicates that these genera were largely confined to or had their maximum development within Gondwanaland, specifically the western part (Fig. 4). This observation appears to be compatible with the assumptions of Truswell (1980), who tentatively divided the Gondwana Province during the Late Permian into the East and West Gondwana provinces. The former is distinguished by a greater diversity of pteridophyte spores, and the latter is characterized by a greater morphological diversity in the gymnosperm pollen group. In addition, Besems \& Schuurman (1987) confirmed the existence of such provincialism during the Late Carboniferous and Early Permian using the microfloral record obtained from the southern part of the Arabian Peninsula.

In conclusion, during the Late Carboniferous/ Early Permian, Egypt's Western Desert, which is in northern Africa, would have been part of the West Gondwana floral province.
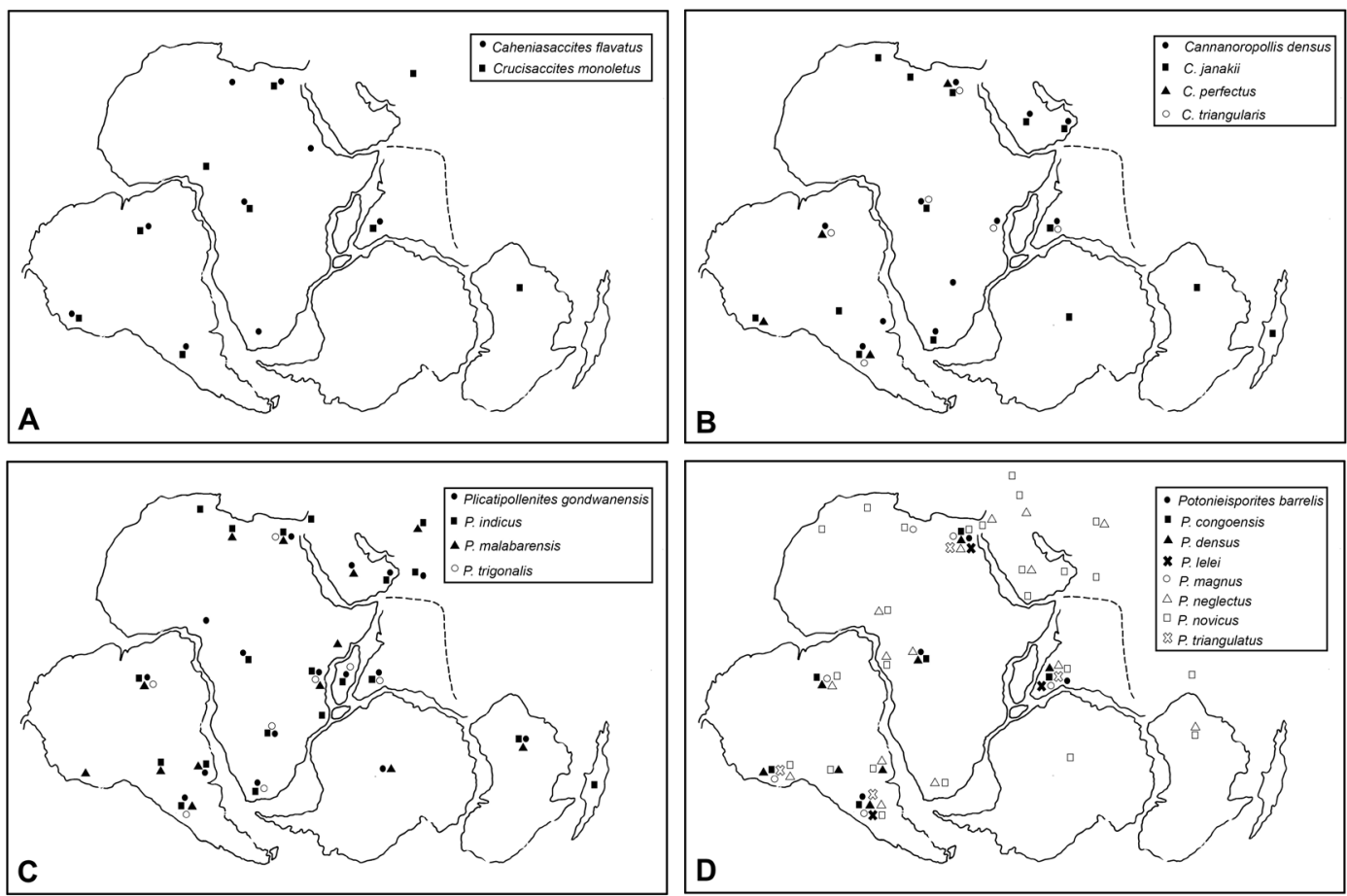

Fig. 4. Geographical distribution of selected monosaccate pollen genera on a re-assembled Gondwanaland. A. Caheniasaccites Bose and Kar emend. Azcuy and di Pasquo; Crucisaccites Lele and Maithy. B. Cannanoropollis Potonié and Sah. C. Potonieisporites Bhardwaj emend. Bharadwaj. D. Plicatipollenites Lele [Sources of data are compiled from Palynodata inc. \& White, 2008 and the present work]. 


\section{Conclusions}

This paper presents the first palynological investigation of the subsurface of the Safi Formation obtained from the Diyur-1 well in the west Beni Suef Basin of Egypt's northern Western Desert, with samples extracted from the significant and remarkably productive shale layers. The study identified 65 miospore taxa, including 31 species of pteridophyte spores (related to 20 genera) and 34 species of gymnosperm pollen (related to 14 genera). No marine palynomorphs were recorded.

The present study refined the age of Safi Foramation previously assigned by Keeley (1989) to Stephanian-Asselian on the basis of the dominance of the diagnostic monosaccate pollen associated with the appearance of the significant taeniate and non- taeniate bisaccate and the Cycadopites pollen taxa.

Based on the possible paleobotanical affinities of the present microflora, we can conclude that the present palynoflora had been derived totally from pteridophyte - gymnosperm vegetation, with the predominance of Coniferopsida, followed by Filicopsida, then Lycopsida, Sphenopsida, Cycadopsida and Ginkgoopsida. This reconstructed vegetation model was found to be almost concordant with the macrofloral fossil records obtained from the Egyptian outcrops during the Late Carboniferous and Early Permian.

The paleoecological significance of the present palynoassemblage revealed the existence of two types of paleoflora during the Late Carboniferous /Early Permian: first, a lowland paleoflora which was dominated by a cold climate wetland fern community associated with some Lycospida, Sphenopsida and Cycadopsida; second, an upland paleoflora which was occupied by a primitive group of gymnospermic plants having a unique moisture-independent reproduction strategy under a glacial climate influence.

A continental interpretation is indicated by palynological and sedimentological evidence, characterizing deposition in front of retreating glacier, with consequent minor fluvial flooding of the lowland areas. The predominance of the typical Gondwanan gymnosperm monosaccate pollen genera supported that the Western Desert belongs to the Western Gondwana floral Province in the Late Carboniferous/ Early Permian time.
Acknowledgements: We are indebted to the authorities of the Egyptian General Petroleum Corporation (EGPC), for providing the samples for this palynological study.

\section{References}

Aboul Ela, N.M. (1989) Palynological evidence for the presence of paraconformity in the Carboniferous carbonates of the Um Bogma Formation, west central Sinai, Egypt. Cairo University Scientific Bulletin, 57, 793-813.

Attar, A., Fournier, J., Candilier, A.M., Coquel, R. (1980) Etude palynologique du Devonien terminal et du Carbonifére inferieur du basin D'illize (FortPolignac) Algerie. Revue de l'Institut Francais $d u$ Pétrole, 35(4), 585-610.

Azcuy, C.L. (1979) A review of the early Gondwana palynology of Argentina and South America. Proceedings of the IV International Palynology Conference, Lucknow 1976-1977, pp. 175-185.

Azcuy, C.L., di Pasquo, M.M., Ampuero, H.V. (2002) Late Carboniferous miospores from the Tarma Formation, Pongo de Mainique, Peru. Review of Palaeobotany and Palynology, 118, 1-28.

Backhouse, J. (1991) Permian palynostratigraphy of the Collie Basin, Western Australia. Review of Palaeobotany and Palynology, 67, 237-314.

Ball, J. (1916) "The Geography and Geology of West Central Sinai, Egypt". Egyptian Survey Department, Cairo. 219p.

Balme, B.E. (1980) Palynology and the CarboniferousPermian boundary in Australia and other Gondwana continents. Palynology, 4, 43-55.

Balme, B.E. (1995) Fossil in situ spores and pollen grains: An annotated catalogue. Review of Palaeobotany and Palynology, 87, 81-323.

Barakat, M.G., Darwish, M. El Barkooky, A.N. (1984) On the occurrence of Ferruginous plant remains in the Upper Carboniferous Sandstones, Sinai, Egypt. NIDOC, Dokki, Cairo, Egypt.

Besems, R.E., Schuurman, W.M.L. (1987) Palynostratigraphy of the Late Palaeozoic glacial deposits of the Arabian Peninsula with special reference to Oman. Palynology, 11, 37-53. 
Boardman, D.R., Souza, P.A., Iannuzzi, R., Mori, L.O. (2012) Paleobotany and palynology of the Rio Bonito Formation (Lower Permian, Paraná basin, Brazil) at the Quitéria outcrop. Ameghiniana, 49(4), 451-472.

Brugman, W.A., Eggink, J.W., Loboziak, S., Visscher, H. (1985) Late Carboniferous-Early Permian (Ghzelian-Artinskian) Palynomorphs. Journal of Micropalaeontology, 4, 93-106.

Brugman, W.A., Loboziak, S., Visscher, H. (1988) The problem of the Carboniferous-Permian boundary in northeast Libya from a palynological point of view. In: "Subsurface Palynostratigraphy of Northeast Libya. Benghazi-Libya", El Arnauti, A., Owens, B., Thusu, B. (Eds.), pp. 151-155. Garyounis University.

Chaloner, W.G., Lacey, W.S. (1973) The distribution of Late Paleozoic floras. In: "Organisms and Continents through Time", Hughes, N.F. (Ed.), pp. 271-289. London: Palaentological Association.

Clayton, G., Coquel, R., Doubinger, J., Gueinn, K.J., Loboziak, S., Owens, B., Streel, M. (1977) Carboniferous Miospores of Western Europe: Illsutration and zonation. Mededelingen Rijsk Geologische Dienst, 29, 1-71.

Clayton, G., Loboziak, S. (1985) Early Carboniferous (Early Viseán-Serpukhovian) palynomorphs, In: Palynostratigraphy of North - East Libya. Journal of Micropalaeontology, 4(1), 83-92.

Darwish, M.H., El Safori, Y. (2016) Late Carboniferous Macroflora from Rod El-Hamal Formation Wadi Araba, North Eastern Desert, Egypt. Taeckholmia, 36, $45-60$.

Dettmann, M.E. (1963) Upper Mesozoic microfloras from southeastern Australia. Proceedings of the Royal Society of Victoria, 77(1), 1-148.

Di Michele, W.A., Pfefferkorn, H.W., Phillips, T.L. (1996) Persistence of Late Carboniferous tropical vegetation during glacially driven climatic and sea-level fluctuations. Palaeogeography Palaeoclimatology Palaeoecology, 125, 105-128.

Di Michele, W.A., Gastaldo, R.A., Pfefferkorn, H.W. (2005) Plant biodiversity partitioning in the Late Carboniferous and Early Permian and its implications for ecosystem assembly. Proceedings of the California Academy of Sciences, 56(1), 32-49.
Di Pasquo, M., Iannuzzi, R. (2014) New palynological information from the Poti Formation (upper Visean) at the Roncador creek, Parnaíba Basin, northeastern Brazil. Boletín Geológico y Minero, 125(4), $405-$ 435.

Eames, L.E. (1984) Palynologic definition of Palaeozoic unconformity-bounded sequences, Gulf of Suez region, Egypt. $7^{\text {th }}$ Exploration Seminar, EGPC, Cairo, pp. 117-125.

EGPC (Egyptian General Petroleum Corporation) (1992) Western Desert, oil and gas fields (A comprehensive Overview). EGPC, Cairo, Egypt. 431p.

El Ghazaly, G., Aly, S.M. (1985) Middle-Upper Devonian and Lower Carboniferous miospores assemblages from Western Desert of Egypt. Qatar University Science Bulletin, 5, 169-186.

El Saadawi, W., Darwish, M.H., Abd EI Azeam, S. (2003) Permian Plant remains from Wadi ELDome, Western Side of the Gulf of Suez, Egypt. Taeckholmia, 23(1), 83-96.

El Shamma, A.A., Abd El Malik, W.M., Baioumi, A.A., Moustafa, T.F. (1996) Microfloral characteristics of some Carboniferous rocks in the Western Desert, Egypt. Assiut UniversityScience Bulletin, 25(2-F), 107-124.

El Shamma, A.A., Mostafa, T.F., Abd El Malik, W.M. (1998) Devonian spores from subsurface rocks in the Western Desert, Egypt. Proceedings of the $14^{\text {th }}$ Petroleum Conference, EGPC, Cairo, 1, pp. 451465.

El Shamma, A.A., Moustafa, T.F., Hosny, A.M. (2012) Tournaisian to Early Permian Miozonations of the Western Desert, Egypt. Journal of American Science, 8(12), 1530-1544.

Grignani, D., Lanzoni, E., El Atrash, H. (1992) Palaeozoic and Mesozoic subsurface palynostratigraphy in the Al-Kufra Basin, Libya. Proceedings of the $3^{\text {th }}$ Symposium on the Geology of Libya (Tripoli). pp. 1159-1227.

Gueinn, K.J., Rasul, S.M. (1986) A contribution to the biostratigraphy of the Palaeozoic of the Western Desert, utilizing new palynological data from the subsurface. Proceedings of the $8^{\text {th }}$ Petroleum Conference, EGPC, Cairo. pp. 1-23. 
Inosova, K.I., Kruzina, A.K., Shwartsman, E.G. (1976) Atlas of microspores and pollen of Upper Carboniferous and Lower Permian of Donets Basin. USSR Ministry of Geology, Order of the Red Banner, Geological Survey Rtemovsk. pp. 1-176.

Jan, I.U., Stephenson, M.H. (2011) Palynology and correlation of the Upper Pennsylvanian Tobra Formation from Zaluch Nala, Salt Range, Pakistan. Palynology, 35(2), 212-225.

Jones, M.J., Truswell, E.M. (1992) Late Carboniferous and Early Permian palynostratigraphy of the Joe Group, southern Galilee Basin, Queensland and implications for Gondwana stratigraphy. $B M R$ Journal of Australian Geology and Geophysics, 13, 143-185.

Keeley, M.L. (1989) The Paleozoic history of the Western Desert of Egypt. Basin Research, 2, 35-48.

Kemp, E.M., Balme, B.E., Helby, R.J., Kyle, R.A., Playford, G., Price, P.L. (1977) Carboniferous and Permian palynostratigraphy in Australia and Antarctica: A review. BMR Journal of Australian Geology and Geophysics, 2, 177-208.

Klitzsch, E. (1990) Palaeozoic. In: "The Geology of Egypt", Said, R. (Ed.), pp. 393-406. Rotterdam: Balkema.

Kora, M. (1993) Carboniferous miospores assemblages from the Abu Rodeiyim boreholes, west central Sinai, Egypt. Revue de Micropaléontologie, 36(3), 235-255.

Kora, M., Schultz, G. (1987) Lower Carboniferous Palynomorphs from Um Bogma, Sinai (Egypt). Grana, 26, 53-66.

Lejal-Nicol, A. (1987) Flores nouvelles du Paleozoiqueet du Mesozoique de L'Egypte et du Soudan septentrional. Berliner geowissenschaftliche Abh (A), $\mathbf{7 5}, 151-248$

Lejal-Nicol, A. (1990) Chapter 29. Fossil flora, In: "The Geology of Egypt", Said, R. (Ed.), pp. 615-625. Rotterdam: Balkema.

Lindström, S. (1995) Early Permian palynostratigraphy of the northern Heimefrontfjella mountain-range, Dronning Maud Land, Antarctica. Review of Palaeobotany and Palynology, 89, 359-415.
Lindström, S. (2003) Carboniferous palynology of the Loppa High, Barents Sea, Norway. Norwegian Journal of Geology, 83, 333-349.

Loboziak, S. (2000) Middle to Late Devonian miospore biostratigraphy of Saudi Arabia. In: "Stratigraphic Palynology of the Paleozoic of Saudi Arabia", AlHajri, S.A., Owens, B. (Eds.), pp. 134-145. GeoArabia Special Publication. Bahrain: Gulf PetroLink.

Loboziak, S., Clayton, G. (1988) The Carboniferous palynostratigraphy of northeast Libya. In: "Subsurface Palynostratigraphy of Northeast Libya", El Arnauti, A., Owens, B., Thusu, B. (Eds.), pp. 129149. Benghazi-Libya: Garyounis University.

Loboziak, S., Streel, M. (1989) Middle-Upper Devonian miospores from the Ghadamis Basin (Tunisia-Libya): Systematic and stratigraphy. Review of Palaeobotany and Palynology, 58, 197-203.

Loboziak, S., Steemans, P., Streel, M., Vachard, D. (1992) Biostratigraphie par miospores du Dévonien inférieur à supérieur du sondage MG-1 (Bassin d'Hammadah, Tunisie) Comparaison avec les données des faunes. Review of Palaeobotany and Palynology, 74, 193205.

Love, C.F. (1994) The palynostratigraphy of the Haushi Group (Westphalian- Artinskian) in Oman. In: "Micropalaeontology and Hydrocarbon Exploration in the Middle East", Simmons, M.D. (Ed.), pp. 23-39. London: Chapman and Hall.

Mahesh, S., Murthy, S., Sabina, K.P., Saran, S., Singh, V.P. (2016) Organic matter characterization of Carbonaceous shales from Raniganj coalfields and its implications on depositional condition: A palynofacies and petrographic overview. Journal of the Geological Society of India, 87, 132-144.

Milani, E.J., Melo, J.H.G., Souza, P.A., Fernandes, L.A., França, A.B. (2007) Bacia do Paraná. Boletim de Geociencias Petrobras, 15(2), 265-287.

Moustafa, T.F., Lashin, G.M.A., Hosny, A.M., El Shamma, A. (2014) Ordovician-Carboniferous palynology of El-waha-1 borehole, Western Desert, Egypt. Indian Journal of Marine Sciences, 43(8), 1484-1499.

Neves, R., Owens, B. (1966) Some Namurian camerate miospores from the English Pennines. Pollen et Spores, 8, 337-360. 
Omara, S., Schultz, G. (1965) Carboniferous microflora from southwestern Sinai, Egypt. Palaeontographica B., 117, 47-58.

Omran, A.M. (1995) Devonian? and Early Carboniferous (Viseán) palynomorphs from the Um Bogma area, southwestern Sinai, Egypt. Assiut University Science Bulletin, 24(2-f), 155-176.

Omran, A.M., Khalifa, H. (1988) Microflora, algae, spores and pollen from Wadi Araba, Eastern Desert, Egypt. Assiut University Science Bulletin, 17(2-f), $1-24$.

Owens, B. (1996) Upper Carboniferous spores and pollen. In: "Palynology: Principles and Applications", Jansonius, J., McGregor, D.C. (Eds.), pp. 597-606. Dallas: AASP Foundation.

Owens, B. Turner, N. (1995) Late Westphalian palynomorphs from northern Saudi Arabia. In: "Palaeozoic Palynostratigraphy of the Kingdom of Saudi Arabia", Owens, B., Al-Tayyar, H., van der Eem, J.G.L.A., Al-Hajri, S. (Eds.), 89, pp. 125-138. Amsterdam: Elsevier; Review of Palaeobotany and Palynology.

Owens, B., Filatoff, J., Clayton, G. Al-Hajri, S. (2000) Evidence of Mid Carboniferous miospores assemblage from Central Saudi Arabia. In: "Stratigraphic Palynology of the Paleozoic of Saudi Arabia", Al-Hajri, S.A., Owens, B. (Eds.), pp. 154167. GeoArabia Special Publication. Bahrain: Gulf PetroLink.

Palynodata Inc, White, J.M. (2008) Palynodata Datafile: 2006 version, with Introduction by White JM. Geological Survey of Canada Open File Report No.: 5793, 1 x CDROM. Available from: http:/geopub. nrcan.gc.ca/moreinfo_e.php?id=225704.

Paris, F., Richardson, J.B., Riegel, W., Streel, M., Vanguestaine, M. (1985) Devonian (EmsianFamennian) palynomorphs. In: "Palynostratigraphy of North-East Libya", Thusu, B., Owens, B. (Eds.). London: The British Micropalaeontological Society. Journal of Micropalaeontology, 4(1), 49-82.

Playford, G., Dino, R. (2000) Palynostratigraphy of the upper Palaeozoic strata (Tapajos Group). Amazonas Basin, Brazil: Part One. Palaeontographica B., 255, $1-46$.

Playford, G., McGregor, D.C. (1993) Miospores and organic-walled microphytoplankton of DevonianCarboniferous boundary beds (Bakken Formation), Southern Saskatchewan: A Systematica and Stratigraphic appraisal. Geological Survey of Canada Bulletin, 445, 1-107.

Ravn, R.L. (1986) Palynostratigraphy of the Lower and Middle Pennsylvanian coals of Iowa. Iowa Geological Survey Technical Paper, 7, 1-245.

Saad, S.I. (1965) Pollen and spores recently discovered in the coals of the Sinai region, 2: Um Bogma District. Palaeontographica B., 115, 139-149.

Schlumberger (1995) Well Evaluation ConferenceEgypt. Houston, Texas, USA. pp. 1-87.

Schrank, E. (1984) Paleozoic and Mesozoic palynomorphs from the Foram-1 well, Western Desert, Egypt. Neues Jahrbuch für Geologie und Paläontologie, 2, 95-112.

Schrank, E. (1987) Paleozoic and Mesozoic palynomorphs from northeast Africa (Egypt and Sudan) with special reference to Late Cretaceous pollen and dinoflagellates. Berliner geowissenschaftliche Abh (A), 75, 249-310.

Schürmann, H.M.E., Burger, D., Dijkstra, J. (1963) Permian near Wadi Araba, Eastern Desert of Egypt. Geologie en Mijnbouw, 42(10), 329-336.

Smith, A.H.V., Butterworth, M.A. (1967) Miospores in the coal seams of the Carboniferous of Great Britain. Palaeontology, 1, 1-324.

Souza, P.A. (2006) Late Carboniferous palynostratigraphy of the Itararé Subgroup, northeastern Paraná Basin, Brazil. Review of Palaeobotany and Palynology, 138, 9-19.

Souza, P.A., Perinotto, J.A.J., Félix, C.M., Araújo, B.C. (2015) Biostratigraphy and paleoecology of an unusual palynological record from the Aquidauana Formation, Late Pennsylvanian of Paraná Basin. Anais da Academia Brasileira de Ciências, 87(2), 611-622.

Srivastava, A.K., Agnihotri, D. (2009) Palaeo-botanical perspective of Satpura Gondwana Basin, Madhya Pradesh. In: Kumar, A., Kushwaha, R.A.S., Thakur, B. (Eds.), pp. 581-595. Earth System Sciences. New Delhi: Concept Publishing Company. 
Stephenson, M.H. (2006) Stratigraphic note: Update of the standard Arabian Permian palynological biozonation: Definition and description of OSPZ5 and 6. GeoArabia, 11(3), 173-178.

Stephenson, M.H., Osterloff, P.L. (2002) Palynology of the deglaciation sequence represented by the Lower Permian Rahab and Lower Gharif Members, Oman. AASP Contributions Series, 40, 1-41.

Stephenson, M.H., Osterloff, P.L., Filatoff, J. (2003) Palynological biozonation of the Permian of Oman and Saudi Arabia: Progress and challenges. GeoArabia, 8, 467-496.

Stephenson, M.H., Leng, M.J., Vane, C.H., Osterloff, P.L., Arrowsmith, C. (2005) Investigating the record of Permian climate change from argillaceous sediments, Oman. Journal of the Geological Society London, 162, 1-11.

Stephenson, M.H., Jan, I.U., Al-Mashaikie, S.Z.A.K. (2013) Palynology and correlation of Carboniferous-Permian glacigene rocks in Oman, Yemen and Pakistan. Gondwana Research, 24(1), 203-211.

Streel, M., Loboziak, S. (1996) Paleozoic spores and pollen; Middle and Upper Devonian miospore. In: "Palynology: Principles and Applications", Jansonius, J., McGregor, D.C. (Eds.), pp. 575-587, Dallas: AASP Foundation.

Streel, M., Paris, F., Riegel, W., Vanguestaine, M.(1988) Acritarchs, chitinozoan and spore stratigraphy from the Middle and Late Devonian of northeast Libya. In: "Subsurface Palynostratigraphy of Northeast Libya", El Arnauti, A., Owens, B., Thusu, B. (Eds.), pp. 111-128. Benghazi-Libya: Garyounis University.
Sultan, I.Z. (1977) Carboniferous miospores from a black shale unit in the Gulf of Suez, Egypt. Sciences Géologiques, bulletins et mémoires, 30(3), 189-201.

Sultan, I.Z. (1986) Palynostratigraphy of Carboniferous rock sequence in Wadi Araba well No. 1, Gulf of Suez region, Egypt. Sciences Géologiques, Bulletins et Mémoires, 39(4), 337-360.

Tawadros, E. (2011) "Geology of North Africa". London: CRC Press. 930p.

Tiwari, R.S., Tripathi, A. (1992) Marker assemblage zones of spores and pollen species through the Gondwana Palaeozoic and Mesozoic sequence in India. Palaeobotanist, 40, 194-236.

Traverse, A. (2007) "Paleopalynology", $2^{\text {nd }}$ ed. Dordrecht: Springer. 813p.

Truswell, E.M. (1980) Permo-Carboniferous palynology of Gondwanaland: progress and problems in the decade to 1980. BMR Journal of Australian Geology and Geophysics, 5, 95-111.

Waksmundzka, M. (2014) Mesozoic spores of Poland-a revision of selected taxa. Biuletyn Pañstwowego Instytutu Geologicznego, 460, 25-88.

Wnuk, C. (1996) The development of floristic provinciality during the Middle and Late Paleozoic. Review of Palaeobotany and Palynology, 90, 5-40.

Wood, G.D., Gabriel, A.M., Lawson, J.C. (1996) Palynological techniques-processing and microscopy. In: "Palynology: Principles and Applications", Jansonius, J., McGregor, D.C., (Eds.), pp. 29-50. Dallas: AASP Foundation. 


\section{أول تسجيل بالينولوجي لتتابع الكربوني العلوي والبرمي السفلي في حوض غرب بني سويف ـ مصر و دلالاته البيئية والجغرافية الكربونية القديمة}

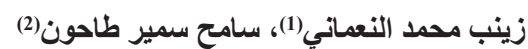

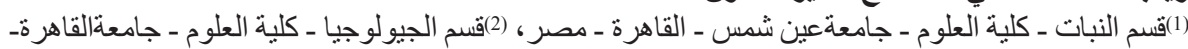

الجيزة - مصر.

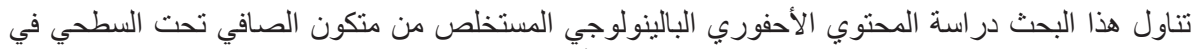

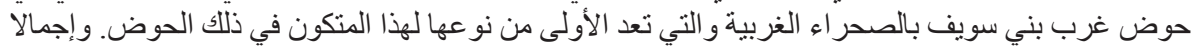

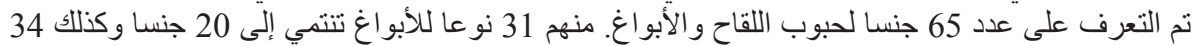



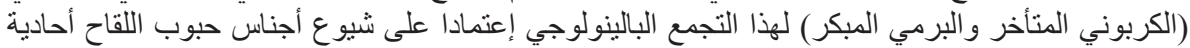

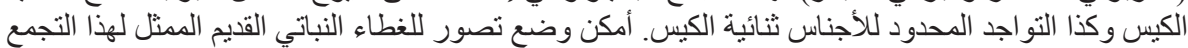

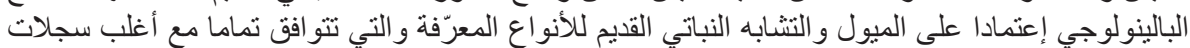

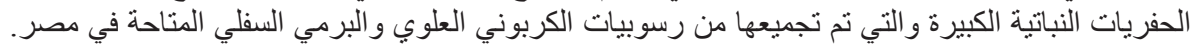

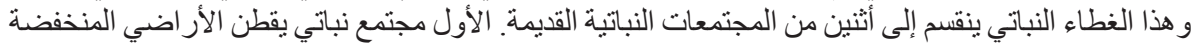

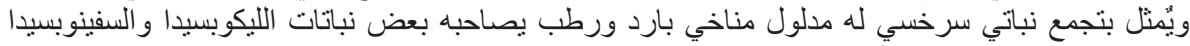

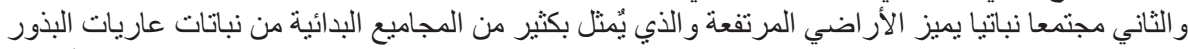

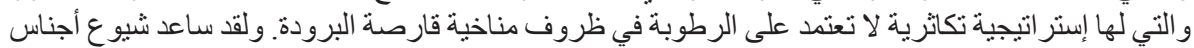

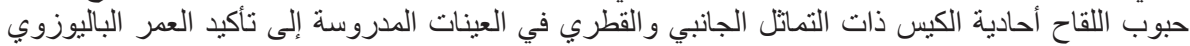

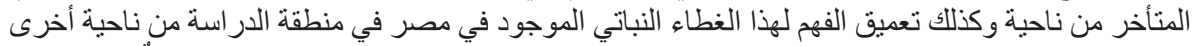

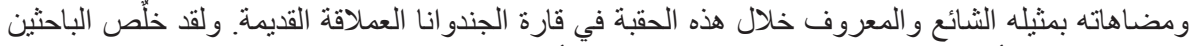

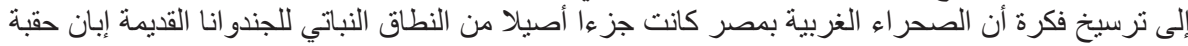
الكربوني المتأخر و البرمي المبكر. 